\title{
Carbonaceous aerosol source apportionment using the Aethalometer model - evaluation by radiocarbon and levoglucosan analysis at a rural background site in southern Sweden
}

\author{
Johan Martinsson ${ }^{1,2}$, Hafiz Abdul Azeem ${ }^{3}$, Moa K. Sporre ${ }^{4}$, Robert Bergström ${ }^{5,6}$, Erik Ahlberg ${ }^{1,2}$ Emilie Öström $^{1,2}$, \\ Adam Kristensson $^{1}$, Erik Swietlicki ${ }^{1}$, and Kristina Eriksson Stenström ${ }^{1}$ \\ ${ }^{1}$ Division of Nuclear Physics, Lund University, Box 118, 22100, Lund, Sweden \\ ${ }^{2}$ Centre for Environmental and Climate Research, Lund University, Ecology Building, 22362, Lund, Sweden \\ ${ }^{3}$ Centre for Analysis and Synthesis, Department of Chemistry, Lund University, Lund, Box 118, 22100, Lund, Sweden \\ ${ }^{4}$ Department of Geosciences, University of Oslo, Postboks 1022, Blindern, 0315, Oslo, Norway \\ ${ }^{5}$ Swedish Meteorological and Hydrological Institute, 60176, Norrköping, Sweden \\ ${ }^{6}$ Department of Chemistry, University of Gothenburg, 41296, Gothenburg, Sweden \\ Correspondence to: Johan Martinsson (johan.martinsson@ nuclear.lu.se)
}

Received: 11 November 2016 - Discussion started: 15 December 2016

Revised: 9 March 2017 - Accepted: 10 March 2017 - Published: 29 March 2017

\begin{abstract}
With the present demand on fast and inexpensive aerosol source apportionment methods, the Aethalometer model was evaluated for a full seasonal cycle (June 2014June 2015) at a rural atmospheric measurement station in southern Sweden by using radiocarbon and levoglucosan measurements. By utilizing differences in absorption of UV and IR, the Aethalometer model apportions carbon mass into wood burning (WB) and fossil fuel combustion (FF) aerosol. In this study, a small modification in the model in conjunction with carbon measurements from thermal-optical analysis allowed apportioned non-light-absorbing biogenic aerosol to vary in time. The absorption differences between WB and FF can be quantified by the absorption Ångström exponent (AAE). In this study $\mathrm{AAE}_{\mathrm{WB}}$ was set to 1.81 and $\mathrm{AAE}_{\mathrm{FF}}$ to 1.0. Our observations show that the AAE was elevated during winter $(1.36 \pm 0.07)$ compared to summer $(1.12 \pm 0.07)$. Quantified WB aerosol showed good agreement with levoglucosan concentrations, both in terms of correlation $\left(R^{2}=0.70\right)$ and in comparison to reference emission inventories. WB aerosol showed strong seasonal variation with high concentrations during winter $\left(0.65 \mu \mathrm{g} \mathrm{m}^{-3}\right.$, $56 \%$ of total carbon) and low concentrations during summer $\left(0.07 \mu \mathrm{g} \mathrm{m}^{-3}, 6 \%\right.$ of total carbon). FF aerosol showed less seasonal dependence; however, black carbon (BC) FF showed clear diurnal patterns corresponding to traffic rush hour peaks. The presumed non-light-absorbing biogenic car-
\end{abstract}

bonaceous aerosol concentration was high during summer $\left(1.04 \mu \mathrm{g} \mathrm{m}^{-3}, 72 \%\right.$ of total carbon) and low during winter $\left(0.13 \mu \mathrm{g} \mathrm{m}^{-3}, 8 \%\right.$ of total carbon). Aethalometer model results were further compared to radiocarbon and levoglucosan source apportionment results. The comparison showed good agreement for apportioned mass of WB and biogenic carbonaceous aerosol, but discrepancies were found for FF aerosol mass. The Aethalometer model overestimated FF aerosol mass by a factor of 1.3 compared to radiocarbon and levoglucosan source apportionment. A performed sensitivity analysis suggests that this discrepancy can be explained by interference of non-light-absorbing biogenic carbon during winter. In summary, the Aethalometer model offers a costeffective yet robust high-time-resolution source apportionment at rural background stations compared to a radiocarbon and levoglucosan alternative.

\section{Introduction}

Carbonaceous aerosol, i.e., the fraction of the aerosol containing carbon, contributes approximately $25 \%$ to the mass of particulate matter with smaller diameter than $10 \mu \mathrm{m}$ $\left(\mathrm{PM}_{10}\right)$ in Europe (Fuzzi et al., 2015) and is presently estimated to be one of the most important climate forcers (IPCC, 
2013). However, the magnitude of the carbonaceous aerosol impact on climate is still associated with significant uncertainty (IPCC, 2013). The carbonaceous aerosol originates mainly from three sources: wood burning, fossil fuel combustion and biogenic emissions. Black carbon (BC) or soot is formed from incomplete combustion of fossil fuels and biofuels. BC has a graphitic carbon structure and is known to efficiently absorb incoming solar radiation (Bond et al., 2013). This absorption leads to molecular vibration and rotation which causes emission of longwave radiation, heating the atmosphere. On the other hand, organic aerosol (OA) is known to mainly scatter incoming sunlight, thereby cooling the climate. Recently, the strongly ultraviolet-absorbing brown carbon $(\mathrm{BrC})$ has gained attention in the scientific community (Laskin et al., 2015; Martinsson et al., 2015; Saleh et al., $2013,2014)$. BrC is emitted in large quantities from wood burning and has been proposed to affect lower tropospheric photochemistry by reducing ultraviolet (UV) radiation (Jacobson, 1999). Although $\mathrm{BrC}$ is a much less effective light absorber than BC, deposition of $\mathrm{BrC}$ on bright surfaces such as snow or ice may cause significant changes in albedo (Doherty et al., 2010).

Carbonaceous aerosols have also been linked to serious health effects, mainly through inhalation (Grahame et al., 2014; Laden et al., 2006; Pope and Dockery, 2006). Carbonaceous aerosols derived from wood burning have been shown to be hazardous to humans (Barregard et al., 2006; Eriksson et al., 2014; Jalava et al., 2010; Naeher et al., 2007; Sehlstedt et al., 2010; Unosson et al., 2013). Additionally, diesel and gasoline vehicles emit large quantities of $\mathrm{BC}$ and associated compounds (e.g., polycyclic aromatic hydrocarbons, PAHs), which have been suggested as one of the most health-damaging particle types (Benbrahim-Tallaa et al., 2012; Hoek et al., 2002; Salvi et al., 1999).

One of the re-emerging air pollutants in Europe is particles from residential wood burning (Denier van der Gon et al., 2015). Wood burning is increasing with approximately $3.5 \%$ per year in Europe due to its potential $\mathrm{CO}_{2}$-neutral effect on climate, while the fossil energy consumption is decreasing by $2 \%$ per year (EEA, 2015). Particle emissions from residential wood burning are usually elevated during winter. It has been estimated that $45-65 \%$ of the total ambient carbonaceous aerosol mass (TC) in Europe is associated with wood burning during this period of the year (Gilardoni et al., 2011; Szidat et al., 2006). Due to the severe climate and health effects from different particle sources, and the importance of wood burning in particular, it is crucial to develop and evaluate source apportionment methods of the carbonaceous aerosols. An accurate source apportionment enables justified mitigation of particle emissions that affect health and climate, as well as a possibility to evaluate emission inventories and chemical transport models.

Levoglucosan is an anhydrosugar formed during pyrolysis of cellulose at temperatures above $300^{\circ} \mathrm{C}$ (Simoneit, 2002). Due to its specificity for cellulose combustion, it has been widely used as a molecular tracer for wood burning in source apportionment studies (Gelencser et al., 2007; Genberg et al., 2011; Yttri et al., 2011a, b). However, there are some drawbacks of using levoglucosan for this purpose. Several studies have shown that levoglucosan may not be stable in the troposphere and that it may react with $\mathrm{OH}$ both in the gas phase (Hennigan et al., 2010; May et al., 2012) and aqueous phase (Hoffmann et al., 2010; Zhao et al., 2014), leading to relatively short estimated atmospheric lifetimes of 1-5 days, depending on the season and atmospheric conditions. The importance of the degradation of levoglucosan in the ambient atmospheric aerosol is still not clarified (Yttri et al., 2015). Also, the relative levoglucosan contribution to the carbonaceous aerosol mass is dependent on combustion conditions (Hedberg and Johansson, 2006). Levoglucosan is most commonly measured on aerosol-laden filters. Filter sampling is generally associated with low time resolution, which makes it difficult to study rapid variations in this source marker.

More recently, the Aethalometer model (Sandradewi et al., 2008a), employing multi-wavelength light-absorbing measurement techniques with high time resolution, has been used for a number of source apportionment studies (Favez et al., 2009, 2010; Herich et al., 2011; Sandradewi et al., 2008a), as an alternative to the methods based on chemical analysis of filter samples. This method relies on the assumption that particles generated from wood burning are relatively more lightabsorbing in the UV than infrared (IR) compared to particles from traffic and other fossil fuel combustion (Kirchstetter et al., 2004). The difference in light absorption can be quantified using the absorption Ångström exponent (AAE), which is a measure of the spectral absorption dependence (Kirchstetter et al., 2004). Wood burning emissions are assumed to have an AAE between 1.5 and 2.5, while traffic and fossil fuel combustion-derived particles exhibits an AAE around 1.0 (Kirchstetter et al., 2004). Despite the great benefits the light-absorption-based source apportionment can offer, with its high time resolution and low costs, the relations between the highly source-specific levoglucosan and light absorption measurement-derived Aethalometer model parameters have so far not been thoroughly investigated. Some studies have found good correlation between levoglucosan and $\mathrm{AAE}$, or calculated $\mathrm{BC}$ from wood burning $\left(\mathrm{BC}_{\mathrm{WB}}\right)$, using the Aethalometer model (Fuller et al., 2014; Herich et al., 2011; Lack et al., 2013). On the other hand, recently published studies claim that the aerosol spectral dependence is more affected by combustion conditions than the type of fuel being combusted (Garg et al., 2016; Martinsson et al., 2015). Garg et al. (2016) found that the gaseous tracer for biomass burning, acetonitrile, correlated well with AAE during smoldering combustion but poorly during flaming combustion, and further that AAE varied greatly throughout combustion of the same fuel type. Calvo et al. (2015) measured levoglucosan in a wood stove with controlled combustion and a traditional fireplace; they found elevated concentrations of levoglucosan during the fuel addition followed by a rapid de- 
crease in concentration in the flaming phase. Hence, it is possible that observed correlations between AAE and levoglucosan may only be valid for the smoldering combustion, which may limit the use of both levoglucosan and AAE as universal tracers of biomass burning.

The aethalometer model has so far mainly been applied during winter in highly polluted urban environments (Favez et al., 2009, 2010; Fuller et al., 2014; Harrison et al., 2013; Sandradewi et al., 2008a). There is thus a lack of knowledge regarding the performance of the Aethalometer model during summer, as well as in less polluted rural environments. For instance, it is not known how the Aethalometer model will cope with the usually dominating and presumably non-lightabsorbing biogenic secondary organic aerosol (SOA) during summer.

This study was initiated with the aim to compare a lightabsorption source apportionment technique, the Aethalometer model (Sandradewi et al., 2008a), to traditional filterbased chemical and physical analysis source apportionment using radiocarbon and levoglucosan measurements for a whole year at a rural measurement station in southern Sweden

\section{Methods}

\subsection{Measurement site and sampling}

Sampling of atmospheric aerosols was conducted at the aerosols, clouds and trace gases research infrastructure (ACTRIS) and European Monitoring and Evaluation Programme (EMEP) rural background station Vavihill, located in southern Sweden $\left(56^{\circ} 01^{\prime} \mathrm{N}, 13^{\circ} 09^{\prime} \mathrm{E} ; 172 \mathrm{~m}\right.$ above sea level). The surrounding landscape consists of coniferous and deciduous forests, farmland and pastures. The measurement station is placed on a pasture that is visited by grazing cattle during spring, summer and fall. The closest large cities are Helsingborg, Malmö and Copenhagen, which are located at distances of 20,50 and $65 \mathrm{~km}$ in the west to southwest direction, respectively. Aerosols were sampled with a $\mathrm{PM}_{10}$ inlet on preheated $\left(900^{\circ} \mathrm{C}\right.$ for $4 \mathrm{~h}$ in air) $47 \mathrm{~mm}$ quartz filters (Pallflex 2500QAT-UP) using a sampling time of $72 \mathrm{~h}$ at a flow rate of $38 \mathrm{~L} \mathrm{~min}^{-1}$ with an automatic Leckel SEQ47/50 sampler. The sampling line consisted of active carbon denuders followed by two quartz filters in series (i.e., front and back filters) with the purpose of correcting for any sampling artifacts caused by volatile organic compounds (VOCs). The installed denuders have shown an efficiency of 90-95\% in a denuder test conducted at Vavihill from 2008 to 2009 (Genberg et al., 2011). However, sampling through active carbon denuders may change the gas-particle equilibrium at the filter, leading to evaporation of semi-volatile compounds from the filter. Genberg et al. (2011) observed that field blanks had similar carbon concentration as the back filters, and consequently concluded that this negative artifact was small. Hence, no correction was considered in the present study. After sampling, filters were put in Petri dishes, wrapped in aluminum foil and stored in a freezer at $-18{ }^{\circ} \mathrm{C}$ until analysis. The total measurement period lasted from June 2014 until June 2015 and included in total 123 filter samples. The measurement period was divided into seasons with 3-month intervals: summer, June-August; fall, September-November; winter, December-February; and spring, March-May.

\section{$2.2 \mathrm{OC} / \mathrm{EC}$ analysis}

Elemental carbon (EC), organic carbon (OC) and total carbon (TC) were measured through thermal-optical analysis (TOA) with a DRI carbon analyzer (model 2001). The EUSAAR_2 analytic protocol was used for the analysis (Cavalli et al., 2010). In short, OC from a $0.5 \mathrm{~cm}^{2}$ filter punch is evolved in four different temperature steps in an inert helium atmosphere at a maximum temperature of $570^{\circ} \mathrm{C}$. A $633 \mathrm{~nm}$ $\mathrm{He} / \mathrm{Ne}$ laser is irradiating the filter and the light transmission through the filter is measured during the increase in temperature. When the measured light transmission reaches its initial baseline value the remaining carbon is considered to be EC. EC is evolved in an oxidizing atmosphere $\left(2 \% \mathrm{O}_{2}\right)$ during high temperatures $\left(500-850^{\circ} \mathrm{C}\right)$. All carbon is oxidized and evolved from the filter as $\mathrm{CO}_{2}$, which is further converted to methane and finally quantified with a flame ionization detector (FID). TC is the sum of OC and EC. Cavalli et al. (2016) estimated the combined random uncertainties from inter-laboratory comparisons between 2008 and 2011 to be $17 \%$ relative standard deviations (RSD) for Vavihill TC measurements.

\subsection{Light absorption measurements and the Aethalometer model}

Aerosol light absorption was measured with an Aethalometer (AE33, Magee Scientific) (Drinovec et al., 2015). The Aethalometer utilizes an airflow through a filter where particles are deposited. The filter deposition spot is irradiated with seven LEDs of different wavelengths $(370,470,520$, $590,660,880,950 \mathrm{~nm}$ ) and the attenuation is calculated per unit of time. In this campaign the Aethalometer was operating with a flow of $5 \mathrm{~L} \mathrm{~min}^{-1}$ through a $\mathrm{PM}_{10}$ inlet at a time resolution of $1 \mathrm{~min}$. Two main measurement artifacts are associated with filter-based light-absorption techniques: the shadowing effect and the filter matrix scattering effect (Weingartner et al., 2003). The AE33 Aethalometer handles these artifacts in two ways: attenuation enhancement due to filter matrix scattering is compensated for by a factor of 1.57 , and the shadowing effect is treated by measuring the attenuation at two filter deposition spots with different depositions rates (Drinovec et al., 2015).

The output data of the Aethalometer are absorption coefficients, $b_{\mathrm{abs}}(\lambda)$, in the units of $\mathrm{m}^{-1} \cdot b_{\mathrm{abs}}(\lambda)$ can be converted into $\mathrm{BC}$ mass concentration units $\left(\mathrm{g} \mathrm{m}^{-3}\right)$ by division 
Table 1. Values of $\mathrm{AAE}_{\mathrm{FF}}$ and $\mathrm{AAE}_{\mathrm{WB}}$ derived from reference emission inventories.

\begin{tabular}{|c|c|c|c|c|}
\hline $\mathrm{AAE}_{\mathrm{FF}}$ & Spectral region & $\mathrm{AAE}_{\mathrm{WB}}$ & Spectral region & References \\
\hline \multirow[t]{3}{*}{1} & $470-660 \mathrm{~nm}$ & 2.1 & $470-660 \mathrm{~nm}$ & Clarke et al. (2007) \\
\hline & & 1.45 & UV-IR & Day et al. (2006) \\
\hline & & 1.4 & UV-IR & Garg et al. (2016) \\
\hline \multirow[t]{7}{*}{0.9} & UV-IR & 2.5 & UV-IR & Kirchstetter et al. (2004) \\
\hline & & 1.9 & UV-IR & Kirchstetter and Thatcher (2012) \\
\hline & & 1.75 & UV-IR & Lewis et al. (2008) \\
\hline & & 1.3 & UV-IR & Martinsson et al. (2015) \\
\hline & & 1.3 & $467-660 \mathrm{~nm}$ & Roden et al. (2006) \\
\hline & & 1.6 & UV-IR & Saleh et al. (2013) \\
\hline & & 2.8 & UV-IR & Sandradewi et al. (2008b) \\
\hline 1.1 & $450-700 \mathrm{~nm}$ & & & Schnaiter et al. (2003) \\
\hline
\end{tabular}

of the mass absorption coefficient (MAC), $\sigma_{\mathrm{abs}}(\lambda)\left(\mathrm{m}^{2} \mathrm{~g}^{-1}\right)$ according to Eq. (1):

$\mathrm{BC}(\lambda)=\frac{b_{\mathrm{abs}}(\lambda)}{\sigma_{\mathrm{abs}}(\lambda)}$

In the Aethalometer model (Sandradewi et al., 2008a), the entire aerosol light absorption is assumed to come from fossil fuel combustion aerosol (FF) or wood burning aerosol (WB):

$b_{\mathrm{abs}}(\lambda)=b_{\mathrm{absFF}}(\lambda)+b_{\mathrm{absWB}}(\lambda)$,

$\frac{b_{\mathrm{absFF}}(370 \mathrm{~nm})}{b_{\mathrm{absFF}}(950 \mathrm{~nm})}=\left(\frac{370}{950}\right)^{-\mathrm{AAE}_{\mathrm{FF}}}$,

$\frac{b_{\text {absWB }}(370 \mathrm{~nm})}{b_{\text {absWB }}(950 \mathrm{~nm})}=\left(\frac{370}{950}\right)^{-\mathrm{AAE}_{\mathrm{WB}}}$.

By combining Eqs. (2)-(4), it is now possible to calculate the light absorption that is caused by WB and FF in 370 and $950 \mathrm{~nm}$ (Mohr et al., 2013; Zotter et al., 2016), respectively:

$b_{\mathrm{absFF}}(950 \mathrm{~nm})=$

$\frac{b_{\mathrm{abs}(370 \mathrm{~nm})}-b_{\mathrm{abs}(950 \mathrm{~nm})} \cdot\left(\frac{370}{950}\right)^{-\mathrm{AAE} \mathrm{WB}_{\mathrm{WB}}}}{\left(\frac{370}{950}\right)^{-\mathrm{AAE}}-\left(\frac{370}{950}\right)^{-\mathrm{AAE}_{\mathrm{WB}}}}$,

$b_{\text {absWB }}(370 \mathrm{~nm})=$

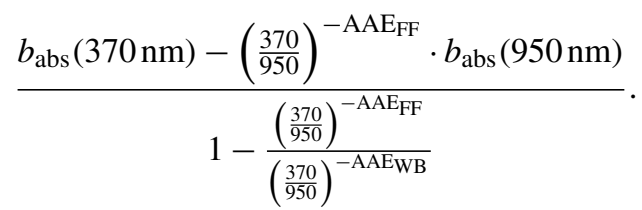

In Eqs. (3)-(6) the AAE is the source-specific spectral dependence. In the Aethalometer model, the selection of source-specific AAEs ( $\mathrm{AAE}_{\mathrm{FF}}$ and $\mathrm{AAE} \mathrm{EB}_{\mathrm{WB}}$ ) is crucial for accurate source contribution estimation. Traditionally, it has been assumed that pure black carbon dominates fossil fuel combustion emission, leading to an $\mathrm{AAE}_{\mathrm{FF}}=1$. Wood burning emissions have previously been assumed to have an AAE around 2 (Kirchstetter et al., 2004). However, recent studies have shown that it is the combustion conditions rather than the fuel itself that determine the organic content in the aerosol and consequently the AAE (Garg et al., 2016; Martinsson et al., 2015). Martinsson et al. (2015) found that flaming combustion in a modern conventional wood stove emitted aerosol with highly agglomerated soot structure and an AAE of 1.3. Garg et al. (2016) determined the combustion efficiency by analyzing emission gas data and reached similar conclusions. We estimated $\mathrm{AAE}_{\mathrm{FF}}$ and $\mathrm{AAE} \mathrm{E}_{\mathrm{WB}}$ based on literature data (Table 1). From Table 1 a mean $\mathrm{AAE}_{\mathrm{FF}}=1.0$ $(\mathrm{SD}=0.1)$ and mean $\mathrm{AAE}_{\mathrm{WB}}=1.81(\mathrm{SD}=0.52)$ was chosen in this study. The value of $\mathrm{AAE}_{\mathrm{WB}}=1.81$ is close to the values chosen by Massabo et al. (2015) and Sandradewi et al. (2008a), i.e., 1.81 and 1.86, respectively.

By using Eqs. (5)-(6) it is possible to calculate the light absorption due to FF $\left(b_{\mathrm{absFF}}(\lambda)\right)$ or $\mathrm{WB}\left(b_{\mathrm{absWB}}(\lambda)\right)$. These light-absorption coefficients can then be divided by the sitespecific MAC (Table 2) in order to calculate the BC mass concentration from each source (Eqs. 7-8):

$\begin{aligned} \mathrm{BC}_{\mathrm{FF}} & =\frac{b_{\mathrm{absFF}}(950 \mathrm{~nm})}{\sigma_{\mathrm{abs}}(950 \mathrm{~nm})}, \\ \mathrm{BC}_{\mathrm{WB}} & =\frac{b_{\mathrm{absWB}}(370 \mathrm{~nm})}{\sigma_{\mathrm{abs}}(370 \mathrm{~nm})} .\end{aligned}$

$\sigma_{\text {abs }}(\lambda)$ is in this case the site-specific mass absorption coefficients for the respective wavelengths, which can be found in Table 2. Site-specific $\sigma_{\text {abs }}(\lambda)$ was determined by linear regression of $b_{\mathrm{abs}}(\lambda)$ against elemental carbon (EC) concentration in $\mathrm{PM}_{10}$. However, it should be noted that $\mathrm{OC}$ also may absorb light, which can result in an overestimated sitespecific $\sigma_{\text {abs }}(\lambda)$ by using the regression between $b_{\text {abs }}(\lambda)$ and EC. However, EC is believed to be a much stronger light absorber than light-absorbing OC (Bond and Bergstrom, 2006; Laskin et al., 2015); therefore, this overestimation is believed to be small. It is also possible to calculate the carbonaceous aerosol mass (CM, i.e., the sum of primary and secondary aerosol) from FF and WB, together with non-light-absorbing secondary aerosol. The latter is presumably mostly derived 
Table 2. Site-specific mass absorption coefficients (MACs) from the Vavihill measurement station. Values were obtained by linear regression analysis of measured absorption coefficients and elemental carbon (EC) concentrations. The slope is equivalent to $\sigma_{\mathrm{abs}}(\lambda)$. Uncertainties are represented by standard errors $(N=123)$.

\begin{tabular}{rr}
\hline$\lambda(\mathrm{nm})$ & $\sigma_{\mathrm{abs}}(\lambda)\left(\mathrm{m}^{2} \mathrm{~g}^{-1}\right)$ \\
\hline 370 & $41.21 \pm 1.00$ \\
470 & $29.06 \pm 0.96$ \\
520 & $24.78 \pm 0.80$ \\
590 & $21.29 \pm 0.68$ \\
660 & $17.57 \pm 0.55$ \\
880 & $12.64 \pm 0.39$ \\
950 & $11.93 \pm 0.37$ \\
\hline
\end{tabular}

from biogenic sources, hence the acronym $\mathrm{CM}_{\mathrm{Bio}}$ :

$$
\begin{aligned}
\mathrm{TC} & =\mathrm{CM}_{\mathrm{FF}}+\mathrm{CM}_{\mathrm{WB}}+\mathrm{CM}_{\mathrm{Bio}} \\
& =\mathrm{C}_{1} \cdot b_{\mathrm{absFF}}(950 \mathrm{~nm})+\mathrm{C}_{2} \cdot b_{\mathrm{absWB}}(370 \mathrm{~nm})+\mathrm{CM}_{\mathrm{Bio}} .
\end{aligned}
$$

In Eq. (9), $C_{1}$ and $C_{2}$ are the slopes from the linear regression of measured total carbonaceous matter (TC) and the light absorption due to FF ( $\left.b_{\mathrm{absFF}}(950 \mathrm{~nm})\right)$ and WB $\left(b_{\mathrm{absWB}}\right.$ $(370 \mathrm{~nm})$ ), respectively. Previous work has set $\mathrm{CM}_{\mathrm{Bio}}$ as the intercept when solving the multilinear equation; however, this is highly unrealistic since biogenic primary and secondary aerosol formation is season-dependent and should vary accordingly (Guenther et al., 1995). We propose an alternative method where $\mathrm{CM}_{\mathrm{Bio}}$ is allowed to vary outside the suggested regressions (Eqs. 10-12). If Eq. (9) is rewritten, a linear regression can be used in order to calculate $\mathrm{C}_{1}$ and $\mathrm{C}_{2}$ :

$$
\begin{aligned}
\frac{\mathrm{TC}}{b_{\mathrm{absWB}}(370 \mathrm{~nm})}= & \mathrm{C}_{1} \cdot \frac{b_{\mathrm{absFF}}(950 \mathrm{~nm})}{b_{\mathrm{absWB}}(370 \mathrm{~nm})} \\
& +\mathrm{C}_{2}+\frac{\mathrm{CM}_{\text {Bio }}}{b_{\mathrm{absWB}}(370 \mathrm{~nm})},
\end{aligned}
$$

$$
\begin{aligned}
\frac{\mathrm{TC}}{b_{\mathrm{absFF}}(950 \mathrm{~nm})}= & \mathrm{C}_{2} \cdot \frac{b_{\mathrm{absWB}}(370 \mathrm{~nm})}{b_{\mathrm{absFF}}(950 \mathrm{~nm})} \\
& +\mathrm{C}_{1}+\frac{\mathrm{CM}_{\mathrm{Bio}}}{b_{\mathrm{absFF}}(950 \mathrm{~nm})} .
\end{aligned}
$$

For Eq. (10), $C_{1}$ can be calculated as the slope of the regression line by setting TC $/ b_{\text {absWB }}(370 \mathrm{~nm})$ as the dependent variable and $b_{\text {absFF }}(950 \mathrm{~nm}) / b_{\text {absWB }}(370 \mathrm{~nm})$ as the independent variable. A similar approach can be applied to Eq. (11) to calculate $\mathrm{C}_{2}$. By selecting only winter data for calculation of $\mathrm{C}_{1}$ and $\mathrm{C}_{2}$ the interference of $\mathrm{CM}_{\mathrm{Bio}}$ is minimized and the division of $\mathrm{CM}_{\mathrm{Bio}}$ by one of the light-absorption parameters is forcing $\mathrm{CM}_{\mathrm{Bio}}$ towards zero. Hence, the intercept of the linear regression line should be close to $\mathrm{C}_{2}$ when calculating the slope as $C_{1}$ in Eq. (10), and vice versa for Eq. (11). The linear fits used to derive $\mathrm{C}_{1}$ and $\mathrm{C}_{2}$ contained one suspected outlier each. These outliers were confirmed by Grubbs test (Grubbs, 1950) for both dependent and independent variables with $95 \%$ confidence and hence removed. The linear fits without outliers are displayed in Figs. S1 and S2. Finally, $\mathrm{CM}_{\mathrm{Bio}}$ is allowed to vary outside the linear regressions:

$\mathrm{CM}_{\mathrm{Bio}}=\mathrm{TC}-\mathrm{CM}_{\mathrm{FF}}-\mathrm{CM}_{\mathrm{WB}}$.

Since $\mathrm{CM}_{\mathrm{Bio}}$ is assumed to be the residual carbonaceous matter, i.e., the carbonaceous matter that does not absorb light, this parameter may have a negative value during winter, when the sum of $\mathrm{CM}_{\mathrm{FF}}$ and $\mathrm{CM}_{\mathrm{WB}}$ exceeds TC.

$\mathrm{C}_{1}$ was calculated to be $214467 \mu \mathrm{g} \mathrm{m}^{-2}$ with an intercept of $133794 . \mathrm{C}_{2}$ was estimated to be $113881 \mu \mathrm{g} \mathrm{m}^{-2}$ with an intercept of 273603 . Hence, $C_{1}$ (from Eq. 10) was deviating $22 \%$ from the intercept in the calculation of $\mathrm{C}_{2}$ (Eq. 11), while $\mathrm{C}_{2}$ (from Eq. 11) was deviating $15 \%$ from the intercept in the calculation of $\mathrm{C}_{1}$ (Eq. 10).

Herich et al. (2011) found high standard errors in their modeled $\mathrm{C}_{1}$ and $\mathrm{C}_{2}$ parameters $( \pm 30 \%)$. This was the main reason for Herich et al. (2011) to exclude the CM approach and proceed with the BC approach presented in Eqs. (7)-(8). In comparison to Herich et al. (2011), we found similar standard error for $\mathrm{C}_{1}(31 \%)$ but lower for $\mathrm{C}_{2}(18 \%)$. We have therefore chosen to proceed with the $\mathrm{CM}$ approach.

\subsection{Levoglucosan analysis}

1,6-Anhydro- $\beta$-D-glucose (levoglucosan) analysis was performed using the method of Wu et al. (2008) with some modifications. Levoglucosan was purchased from SigmaAldrich (St. Louis, USA). Hexane from Scharlau (Spain), 1-phenyldodecane, $97 \%$ from Acros Organics (Geel, Belgium) and $\mathrm{N}, \mathrm{O}$-bis(trimethylsilyl)trifluoroacetamide (BSTFA) containing $1 \%$ trimethylsilyl chloride (TMCl) was purchased from Sigma (St. Louis, USA). Filter punches were divided into small pieces using a surgical blade and placed in a $50 \mathrm{~mL}$ conical flask. Extraction was carried out by sonication using three aliquots of 15,10 and $10 \mathrm{~mL}$ of dichloromethane and methanol (1:3) for 45, 30 and $15 \mathrm{~min}$ respectively. Extract from each step was filtered and pooled together in a $50 \mathrm{~mL}$ beaker using a $0.45 \mu \mathrm{m}$ polypropylene membrane syringe filter. The total extract was concentrated to dryness under a gentle stream of nitrogen at $60^{\circ} \mathrm{C}$. The final volume of the extract was made up to $1 \mathrm{~mL}$ with dichloromethane.

From each extract, $50 \mu \mathrm{L}$ was placed in gas chromatography (GC) vials with $300 \mu \mathrm{L}$ glass inserts and evaporated to dryness under a gentle stream of nitrogen at $60^{\circ} \mathrm{C}$. Then, $15 \mu \mathrm{L}$ of 1-phenyldodecane (97\% Acros Organics, internal standard) solution prepared in hexane $\left(1 \mu \mathrm{g} \mathrm{mL}^{-1}\right)$ and $10 \mu \mathrm{L}$ of $\mathrm{N}, \mathrm{O}$-bis(trimethylsilyl)trifluoroacetamide (BSTFA) containing $1 \%$ trimethylsilyl chloride $(\mathrm{TMCl})$ were added to the vials (Sigma-Aldrich). The vials were sealed using screw caps with Teflon septa. Samples were derivatized in an oven at $80^{\circ} \mathrm{C}$ for $1 \mathrm{~h}$. Solvent blanks and calibration curve were 
run for each batch of eight samples. Samples were analyzed immediately after derivatization.

An Agilent 6890 series GC with 5973 MS (Agilent Technologies, Palo Alto, USA) was used for the analysis. An Agilent HP-5ms column $(30 \mathrm{~m} \times 0.25 \mathrm{~mm} \times 0.25 \mu \mathrm{m}$ film thickness) was used. Injection volume was $2 \mu \mathrm{L}$, splitless, with injector temperature of $280^{\circ} \mathrm{C}$. The temperature program was as follows: initial temperature $60^{\circ} \mathrm{C}$ for $3 \mathrm{~min}$, then raised to $190^{\circ} \mathrm{C}$ at a rate of $10^{\circ} \mathrm{C} \mathrm{min}^{-1}$, and then finally raised to $300^{\circ} \mathrm{C}$ at a rate of $30^{\circ} \mathrm{C} \mathrm{min}^{-1}$. Transfer line, ion source and quadruple temperatures were 280,250 and $180^{\circ} \mathrm{C}$, respectively. The MS was operated in electron ionization mode. Scan mode was used to identify levoglucosan (99\% pure, Sigma-Aldrich) and 1-phenyldodecane with $m / z 217$ and 246 respectively. The exact masses used for calibration curves and aerosol samples were determined by SIM mode as $m / z 217.3$ and 246.3, respectively. The measurement uncertainty in SD of the GC-MS measurements was estimated to be $\pm 1 \%$ of the levoglucosan peak areas.

\section{$2.5{ }^{14} \mathrm{C}$ analysis}

The ${ }^{14} \mathrm{C} /{ }^{12} \mathrm{C}$ ratio in the sampled particles was measured with accelerator mass spectrometry (AMS) (Hellborg and Skog, 2008) by using the $250 \mathrm{kV}$ single-stage AMS at Lund University (Skog, 2007; Skog et al., 2010). Prior to the analysis, the carbon in the particle filter sample was transformed to graphite according to the procedure described in Genberg et al. (2010). In brief, a filter sample corresponding to approximately $50 \mu \mathrm{g}$ of carbon was mixed with $\mathrm{CuO}$ and combusted in a vacuum. Evolved $\mathrm{CO}_{2}$ was purified cryogenically, mixed with $\mathrm{H}_{2}$ and heated to $600{ }^{\circ} \mathrm{C}$ in the presence of an iron catalyst. In the latter reaction the $\mathrm{CO}_{2}$ was reduced into graphite. The results are presented as fraction of modern carbon, $\mathrm{F}^{14} \mathrm{C}$ (Reimer et al., 2004). An $\mathrm{F}^{14} \mathrm{C}$ value of 1 represents the 1950 concentration of ${ }^{14} \mathrm{C}$ excluding human influences. The true atmospheric ${ }^{14} \mathrm{C}$ content has, however, been altered due to two effects, known as the bomb effect (Rafter and Fergusson, 1957) and the Suess effect (Suess, 1955). The bomb effect, which is referring to atmospheric testing of thermonuclear weapons in the 1940-1960s, has had a positive effect on the $\mathrm{F}^{14} \mathrm{C}$ values, due to neutron-induced reactions forming ${ }^{14} \mathrm{C}$. The Suess effect is the result of emission of $\mathrm{CO}_{2}$ from anthropogenic fossil fuel combustion, leading to the ongoing increase in the atmospheric $\mathrm{CO}_{2}$ concentration. Since fossil fuels are ${ }^{14} \mathrm{C}$-free, the Suess effect generates decreased $\mathrm{F}^{14} \mathrm{C}$ values of atmospheric carbon (Baxter and Walton, 1970). Estimated measurement uncertainties expressed as SD are typically $\pm 1 \%$ of measurement values.

Prior to the $\mathrm{F}^{14} \mathrm{C}$ measurements, 104 out of 123 filter samples were pooled with a neighboring sample due to limited amount of filter material. In the pooled samples, filter material corresponding to $25 \mu \mathrm{g} \mathrm{C}$ was punched out from each of the two filter samples, resulting in the desirable mass of $50 \mu \mathrm{g}$ C. Two pooled samples (19-25 December 2014 and
17-23 February 2015) were omitted due to failure in the graphitization process and consequently lack of filter material.

Evaluation of the Aethalometer model results was performed using mainly $\mathrm{F}^{14} \mathrm{C}$ data and the source apportionment approach by Bonvalot et al. (2016). The ambient carbonaceous aerosol can be assumed to be composed of one fossil and one non-fossil fraction. Determination of the non-fossil fraction $\left(f_{\mathrm{NF}}\right)$ is performed by normalizing the measured $\mathrm{F}^{14} \mathrm{C}\left(\mathrm{F}^{14} \mathrm{C}_{\mathrm{S}}\right)$ by a non-fossil reference value $\left(\mathrm{F}^{14} \mathrm{C}_{\mathrm{NF}}\right.$,ref $)$ :

$f_{\mathrm{NF}}=\frac{\mathrm{F}^{14} \mathrm{C}_{\mathrm{S}}}{\mathrm{F}^{14} \mathrm{C}_{\mathrm{NF}} \text {,ref }}$.

A previous source apportionment study at Vavihill suggests that winter samples are highly influenced by wood burning but low levels of other modern carbon sources, i.e., biogenic primary and secondary aerosol (Genberg et al., 2011). Biomass used for wood burning has usually had a growth period of decades, implying that the integrated average $\mathrm{F}^{14} \mathrm{C}$ for wood burning is higher than the atmospheric $\mathrm{F}^{14} \mathrm{C}$ at the time of sampling. As in previous studies, we also assume that the biomass used in wood burning has an average $\mathrm{F}^{14} \mathrm{C}_{\mathrm{WB}}$ of 1.10 (Szidat et al., 2006; Bonvalot et al., 2016). Hence, we use $\mathrm{F}^{14} \mathrm{C}_{\mathrm{NF}}$,ref $=1.10$ during winter.

Summer carbonaceous aerosol mass at Vavihill has been found to be dominated by biogenic primary and secondary organic aerosol (Genberg et al., 2011; Yttri et al., 2011a). Hence, the summertime carbonaceous aerosol should have a $\mathrm{F}^{14} \mathrm{C}$ close to the atmospheric value at the sampling time, i.e., $\mathrm{F}^{14} \mathrm{C}_{\mathrm{Bio}}=1.04$. Thus, summertime $\mathrm{F}^{14} \mathrm{C}_{\mathrm{NF}}$, ref was set to 1.04 . Spring and fall are characterized by highly mixed sources of modern carbon. It can be expected that both wood burning and biogenic emissions contribute significantly to the carbonaceous mass during these seasons. We therefore chose the mean of winter and summer $\mathrm{F}^{14} \mathrm{C}_{\mathrm{NF}}$, ref to represent the spring and fall samples, i.e., 1.07. The total carbon can be assumed to be derived from three possible sources:

$\mathrm{TC}=\mathrm{TC}_{\mathrm{NF}}+\mathrm{TC}_{\mathrm{FF}}=\mathrm{TC}_{\mathrm{WB}}+\mathrm{TC}_{\mathrm{Bio}}+\mathrm{TC}_{\mathrm{FF}}$.

In Eq. (14), sample TC is divided into non-fossil (NF) and fossil fractions (FF). NF can be further subdivided into wood burning (WB) and biogenic carbon (Bio). From Eq. (14) it is now possible to set up the ${ }^{14} \mathrm{C}$ mass balance equation:

$$
\begin{aligned}
\mathrm{TC} \cdot \mathrm{F}^{14} \mathrm{C}_{\mathrm{S}}= & \mathrm{TC}_{\mathrm{WB}} \cdot \mathrm{F}^{14} \mathrm{C}_{\mathrm{WB}}+\mathrm{TC}_{\mathrm{Bio}} \cdot \mathrm{F}^{14} \mathrm{C}_{\mathrm{Bio}} \\
& +\mathrm{TC}_{\mathrm{FF}} \cdot \mathrm{F}^{14} \mathrm{C}_{\mathrm{FF}} .
\end{aligned}
$$

In Eq. (15) $\mathrm{F}^{14} \mathrm{C}_{\mathrm{S}}$ is the sample $\mathrm{F}^{14} \mathrm{C} . \mathrm{F}^{14} \mathrm{C}_{\mathrm{WB}}, \mathrm{F}^{14} \mathrm{C}_{\mathrm{Bio}}$ and $\mathrm{F}^{14} \mathrm{C}_{\mathrm{FF}}$ are the reference $\mathrm{F}^{14} \mathrm{C}$ value for each of the respective sources. Since $\mathrm{F}^{14} \mathrm{C}_{\mathrm{FF}}$ is equal to zero, this gives

$\mathrm{TC} \cdot \mathrm{F}^{14} \mathrm{C}_{\mathrm{s}}=\mathrm{TC}_{\mathrm{WB}} \cdot \mathrm{F}^{14} \mathrm{C}_{\mathrm{WB}}+\mathrm{TC}_{\mathrm{Bio}} \cdot \mathrm{F}^{14} \mathrm{C}_{\mathrm{Bio}}$.

$\mathrm{TC}$ non-fossil ( $\mathrm{TC}_{\mathrm{NF}}$ ) can be calculated by Eq. (17):

$\mathrm{TC}_{\mathrm{NF}}=\mathrm{TC} \cdot \mathrm{f}_{\mathrm{NF}}$. 
Table 3. Definition of wind directions of incoming air masses.

\begin{tabular}{ll}
\hline Direction & Degrees $\left(^{\circ}\right)$ \\
\hline Northeast (NE) & $0-90$ \\
Southeast (SE) & $90-180$ \\
Southwest (SW) & $180-270$ \\
Northwest (NW) & $270-360$ \\
\hline
\end{tabular}

Total carbon from wood burning $\left(\mathrm{TC}_{\mathrm{WB}}\right)$ can then be calculated by Eq. (18):

$\mathrm{TC}_{\mathrm{WB}}=a \cdot[$ levoglucosan $]$.

Here, $a$ is the slope from the linear fit between $\mathrm{TC}_{\mathrm{NF}}$ and levoglucosan for winter samples (Fig. S3), [levoglucosan] is the sample levoglucosan concentration. Only winter samples are used and the linear fit is forced through origin with the purpose of minimizing the effect of biogenic carbon on $\mathrm{TC}_{\mathrm{NF}}$. Hence, we assume that all non-fossil carbon is derived from wood burning during winter. However, it should be noted that combustion of fossil lignite (i.e., brown coal) can emit large quantities of levoglucosan and be confused with wood combustion (Fabbri et al., 2008). It is now possible to calculate the total carbon from biogenic sources:

$\mathrm{TC}_{\mathrm{Bio}}=\frac{\mathrm{F}^{14} \mathrm{C}_{\mathrm{S}} \cdot \mathrm{TC}-\mathrm{TC}_{\mathrm{WB}} \cdot \mathrm{F}^{14} \mathrm{C}_{\mathrm{WB}}}{\mathrm{F}^{14} \mathrm{C}_{\mathrm{Bio}}}$.

In Eq. (19), $\mathrm{F}^{14} \mathrm{C}_{\mathrm{S}}$ is the sample $\mathrm{F}^{14} \mathrm{C}, \mathrm{F}^{14} \mathrm{C}_{\mathrm{WB}}=1.10$ and $\mathrm{F}^{14} \mathrm{C}_{\mathrm{Bio}}=1.04$ (Bonvalot et al., 2016). Finally, it is possible to derive $\mathrm{TC}_{\mathrm{FF}}$ :

$\mathrm{TC}_{\mathrm{FF}}=\mathrm{TC}-\mathrm{TC}_{\mathrm{WB}}-\mathrm{TC}_{\mathrm{Bio}}$.

\subsection{HYSPLIT}

The Hybrid Single Particle Lagrangian Integrated Trajectory Model (HYSPLIT) (Draxier and Hess, 1998; Stein et al., 2015) was used to study the history of the air mass carrying the particles sampled on the filters and measured by the Aethalometer. Gridded meteorological data from the National Centers for Environmental Prediction (NCEP) Global Data Assimilation System (GDAS) were used as input to trajectory model. Back-trajectories were calculated at an hourly frequency $120 \mathrm{~h}$ backward in time and the trajectories started $100 \mathrm{~m}$ above ground at the Vavihill measurement site. For each filter sample, 72 trajectories were used since the sampling time was $72 \mathrm{~h}$. Four regions of origin (Table 3) were defined and for each sample it was investigated how much time the air mass had spent over each of the regions of origin. Also, the accumulated precipitation along each trajectory during the last $24 \mathrm{~h}$ before arrival at Vavihill was used to evaluate the effect of precipitation on aerosol particle concentration. For each sample, the accumulated precipitation along each of the 72 the trajectories was summarized.

\subsection{Auxiliary measurements}

$\mathrm{NO}_{X}$ was continuously monitored with a time resolution of $1 \mathrm{~h}$ with a CLD $700 \mathrm{AL}$ chemiluminescence analyzer (Eco Physics, Duernten, Switzerland). The detection limit was $1 \mathrm{ppb}$. Mass concentration of $\mathrm{PM}_{10}$ was monitored with a tapered element oscillating microbalance (TEOM, 8500 FDMS, Thermo Fisher Scientific). The time resolution was $1 \mathrm{~h}$ and detection limit $0.1 \mu \mathrm{g} \mathrm{m}^{-3}$.

\section{Results and discussion}

\subsection{Variations and features in carbon concentrations}

Carbonaceous aerosol constitutes on average $13 \%$ of the total $\mathrm{PM}_{10}$ during the measurement period. Figure $1 \mathrm{a}-\mathrm{b}$ displays the temporal variation in particulate carbon throughout the measurement period. OC is elevated during summer $\left(\right.$ mean $\left.=1.29 \mu \mathrm{g} \mathrm{m}^{-3}\right)$ and fall $\left(\right.$ mean $\left.=1.86 \mu \mathrm{g} \mathrm{m}^{-3}\right)$ and then decreases during winter $\left(\right.$ mean $=0.96 \mu \mathrm{g} \mathrm{m}^{-3}$ ) and spring (mean $=1.19 \mu \mathrm{g} \mathrm{m}^{-3}$ ). EC peaked during fall (mean $=0.32 \mu \mathrm{g} \mathrm{m}^{-3}$ ), while the concentrations during winter $\left(\right.$ mean $\left.=0.19 \mu \mathrm{g} \mathrm{m}^{-3}\right)$, spring $\left(\right.$ mean $\left.=0.21 \mu \mathrm{g} \mathrm{m}^{-3}\right)$, and summer (mean $\left.=0.14 \mu \mathrm{g} \mathrm{m}^{-3}\right)$ were significantly lower $(p<$ 0.05 , Fig. 1b).

A discrepancy in winter concentrations of carbonaceous compounds was found between this study (2014-2015) and a previous Vavihill source apportionment study (2008-2009). Genberg et al. (2011) found elevated concentrations of OC during winter $\left(2.19 \mathrm{\mu g} \mathrm{m}^{-3}, p<0.1\right)$ and approximately twice the amount of EC during winter compared to summer ( 0.30 vs. $0.14 \mu \mathrm{g} \mathrm{m}^{-3}, p<0.001$ ). EC is typically elevated during the cold period of the year, when residents burn wood for heating. In the present study we found no significant differences in OC or EC between summer and winter. Figure 1a reveals a decrease in carbonaceous aerosol mass concentration during winter, from the beginning of December 2014 to mid-February 2015. In fact, by comparing the measurement campaign TC during the winter 2014-2015 with the average TC during earlier winters we found that the TC concentration during the winter 2014-2015 was 35\% lower than the average winter of 2008-2013 ( $p=0.024$, Fig. S4). By using HYSPLIT we find that the incoming air masses to Vavihill during the winter of this measurement campaign were influenced by approximately $45 \%$ more precipitation than the average winter of 2000-2013 ( $p=0.002$, Fig. S5). Furthermore, we found a weak but significant negative relationship between precipitation and TC $\left(R^{2}=0.1 ; p<0.05\right)$. Wet deposition losses are thus likely to be at least a partial explanation of lower wintertime concentrations of carbonaceous aerosol in this study. 

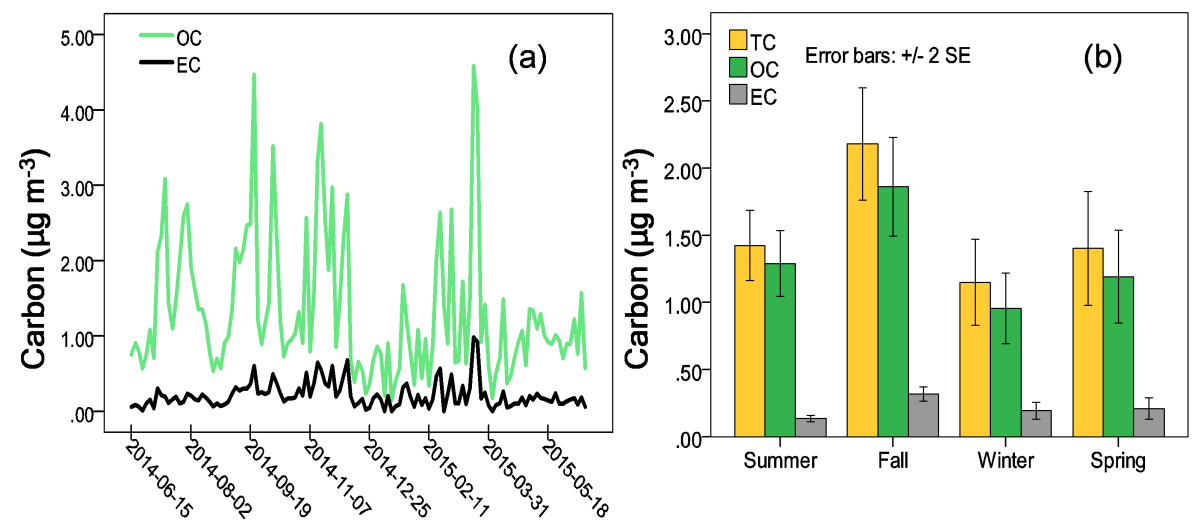

Figure 1. Temporal variations in OC, EC and TC. Panel (a) shows the temporal variation in OC and EC with a time resolution of $72 \mathrm{~h}$ $(N=123)$. Panel (b) displays the average concentration of TC, OC and EC divided into seasons: summer $(N=32)$, fall $(N=30)$, winter $(N=30)$ and spring $(N=31)$. Error bars display \pm 2 standard errors $(\mathrm{SE})$.

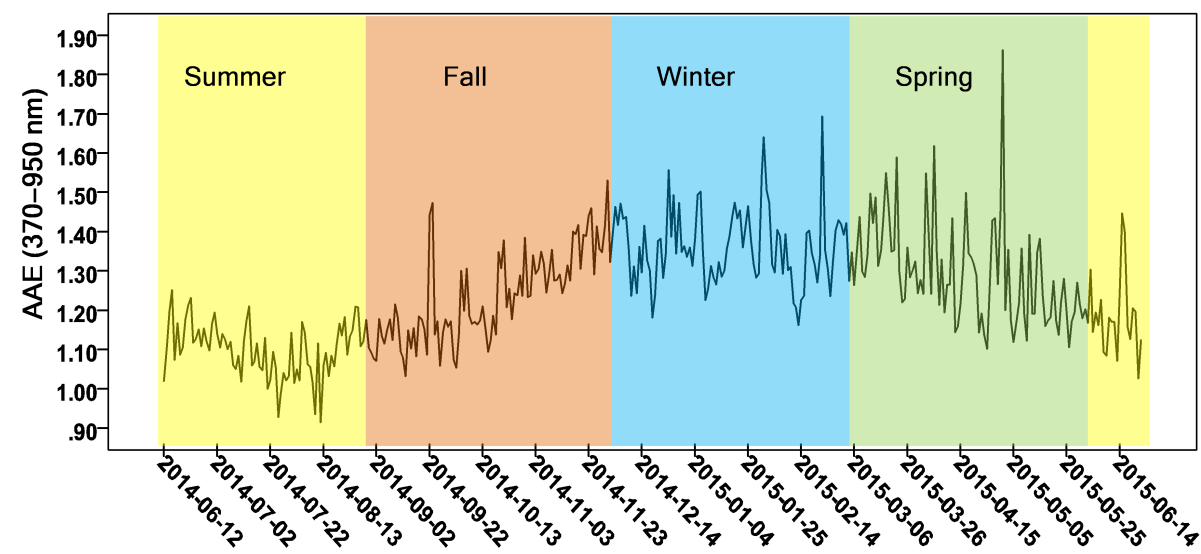

Figure 2. Annual variations in AAE $(370-950 \mathrm{~nm})$ at the Vavihill measurement station. Colors represent different seasons of the year. $N=369$.

\subsection{Variations in light-absorption measurements and Aethalometer-model-derived parameters}

Figure 2 shows the AAE throughout the whole measurement campaign (June 2014-June 2015). In general, there was a strong negative relationship between AAE and ambient temperature $\left(R^{2}=0.74 ; p<0.001\right)$. During summer the AAE remains low in the range of 1.0-1.2 (mean $=1.12$; standard deviation $=0.07)$. An increase in AAE follows during the fall $($ mean $=1.23 ; \mathrm{SD}=0.1)$ and stays at $1.2-1.5($ mean $=1.36$; $\mathrm{SD}=0.07)$ throughout the winter period. In the spring, the $\mathrm{AAE}$ remains high (mean $=1.31 ; \mathrm{SD}=0.09$ ), but is decreasing towards 1.1-1.2 at the end of the season. There is a significant difference in AAE between all seasons $(p<0.01)$, except between winter and spring $(\mathrm{p}=0.055)$. The observed seasonal pattern is in accordance with earlier studies by Sandradewi et al. (2008b) and Herich et al. (2011), who found elevated AAE of 1.3-1.6 during winter and a decreased AAE of around 1.0 during summer.
Elevated AAE during the cold period of the year is most likely caused by increased use of wood burning for residential heating, this has been confirmed in several studies (Genberg et al., 2011; Herich et al., 2011; Sandradewi et al., 2008b). Since the measured aerosol light absorption most likely is a mixture of fossil and wood burning the selection of AAEs for the Aethalometer model calculations are supported by the observed seasonal pattern - i.e., the observed $\mathrm{AAE}$ varies between $\mathrm{AAE}_{\mathrm{FF}}$ and $\mathrm{AAE} \mathrm{WB}_{\mathrm{WB}}$.

Figure 3 shows the diurnal variation in AAE (370$950 \mathrm{~nm}), \mathrm{BC}_{\mathrm{FF}}, \mathrm{BC}_{\mathrm{WB}}$ and $\mathrm{NO}_{X}$ between summer and winter and between weekdays and weekends. There is a minimum in AAE at 07:00-10:00 (local time, Fig. 3a-b), this coincides with morning traffic rush hours. Sandradewi et al. (2008b) found similar results during winter with a minimum in AAE around 08:00. This result is confirmed by data presented in Fig. 3d, which shows the calculated $\mathrm{BC}_{\mathrm{FF}}$ $(950 \mathrm{~nm})$ from the Aethalometer model. It is clear that there is a peak at 08:00-10:00 and at 17:00-19:00 in the $\mathrm{BC}_{\mathrm{FF}}$ 

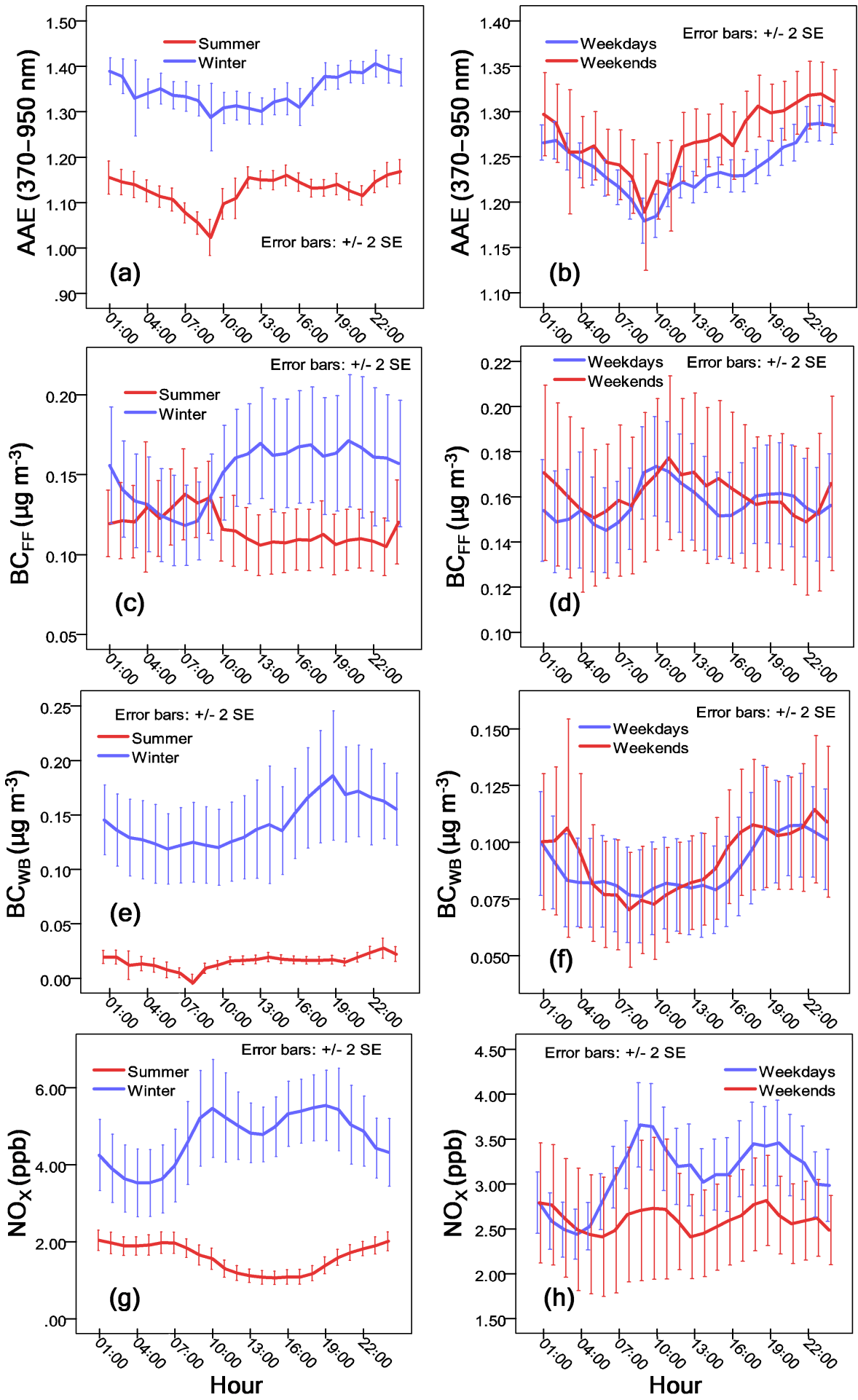

Figure 3. Diurnal variations in AAE $(370-950 \mathrm{~nm}, \mathbf{a}-\mathbf{b}), \mathrm{BC}_{\mathrm{FF}}(950 \mathrm{~nm}, \mathbf{c}-\mathbf{d}), \mathrm{BC}_{\mathrm{WB}}\left(370 \mathrm{~nm}\right.$, e-f) and $\mathrm{NO}_{X}(\mathbf{g}-\mathbf{h})$ at the Vavihill measurement station. Panels (a), (c), (e) and (g) represent diurnal differences between summer and winter, while panels (b), (d), (f), and (h) represents diurnal differences between weekdays (Monday-Friday) and weekends (Saturday-Sunday, including national holidays). Uncertainties are given as 2 times the standard error (SE). 
Table 4. Seasonal mean concentrations and contributions to $\mathrm{PM}_{10}$ and TC of Aethalometer-model-derived parameters. Uncertainties are given in standard deviations.

\begin{tabular}{|c|c|c|c|c|c|c|c|c|c|}
\hline \multirow[b]{2}{*}{ Season } & \multicolumn{3}{|c|}{ Concentration $\left(\mu \mathrm{g} \mathrm{m}^{-3}\right)$} & \multicolumn{3}{|c|}{ Contribution to $\mathrm{PM}_{10}(\%)$} & \multicolumn{3}{|c|}{ Contribution to TC $(\%)$} \\
\hline & $\mathrm{CM}_{W B}$ & $\mathrm{CM}_{\mathrm{FF}}$ & $\mathrm{CM}_{\text {Bio }}$ & $\mathrm{CM}_{W \mathrm{~B}}$ & $\mathrm{CM}_{\mathrm{FF}}$ & $\mathrm{CM}_{\text {Bio }}$ & $\mathrm{CM}_{\mathrm{WB}}$ & $\mathrm{CM}_{\mathrm{FF}}$ & $\mathrm{CM}_{\mathrm{Bio}}$ \\
\hline Summer & $0.07 \pm 0.05$ & $0.31 \pm 0.19$ & $1.04 \pm 0.59$ & $0.6 \pm 0.4$ & $2.7 \pm 1.1$ & $9.0 \pm 2.8$ & $6.1 \pm 4.0$ & $21.5 \pm 6.9$ & $72.4 \pm 6.5$ \\
\hline Fall & $0.49 \pm 0.46$ & $0.62 \pm 0.36$ & $1.06 \pm 0.68$ & $2.6 \pm 1.9$ & $3.7 \pm 1.1$ & $6.8 \pm 3.4$ & $22.2 \pm 14.9$ & $28.4 \pm 8.0$ & $49.3 \pm 19.8$ \\
\hline Winter & $0.65 \pm 0.53$ & $0.37 \pm 0.25$ & $0.13 \pm 0.21$ & $5.4 \pm 3.5$ & $3.1 \pm 1.3$ & $0.9 \pm 1.6$ & $56.5 \pm 13.3$ & $35.5 \pm 9.4$ & $8.0 \pm 14.4$ \\
\hline Spring & $0.51 \pm 0.69$ & $0.35 \pm 0.30$ & $0.54 \pm 0.32$ & $4.9 \pm 3.5$ & $3.9 \pm 2.1$ & $8.9 \pm 9.6$ & $32.3 \pm 17.9$ & $25.6 \pm 9.0$ & $42.1 \pm 22.5$ \\
\hline
\end{tabular}

emissions. This pattern is validated by $\mathrm{NO}_{X}$ concentrations showing similar diurnal pattern as $\mathrm{BC}_{\mathrm{FF}}(\mathrm{Fig}$. $3 \mathrm{~g}-\mathrm{h})$, although the diurnal variation is stronger for the $\mathrm{NO}_{X}$ concentrations. Rissler et al. (2014) found similar peaks in $\mathrm{NO}_{X}$ and $\mathrm{BC}$ from a busy road in Copenhagen. A major source of $\mathrm{NO}_{X}$ is vehicle combustion engines and $\mathrm{NO}_{X}$ can thus be expected to correlate with $\mathrm{BC}_{\mathrm{FF}}$. Due to the rural location of Vavihill measurement station, it may take $2-3 \mathrm{~h}$ for the traffic emissions to reach the station if they originate from the major cities in the region; this can explain why the $\mathrm{NO}_{X}$ (and $\mathrm{BC}_{\mathrm{FF}}$ ) peaks occur somewhat later at Vavihill than expected traffic rush hours. Studying the long-term pattern between $\mathrm{BC}_{\mathrm{FF}}$ and $\mathrm{NO}_{X}$, there is a weak but significant correlation throughout the whole measurement campaign $\left(R^{2}=0.09\right.$; $p<0.001)$. However, since $\mathrm{NO}_{X}$ is efficiently oxidized by $\mathrm{OH}$ radicals and ozone during periods with high UV radiation it is more suitable to compare these on a seasonal basis. Significant but very weak correlations between $\mathrm{BC}_{\mathrm{FF}}$ and $\mathrm{NO}_{X}$ were found during fall $\left(R^{2}=0.07 ; p=0.021\right)$, winter $\left(R^{2}=0.2 ; p<0.001\right)$, spring $\left(R^{2}=0.41 ; p<0.001\right)$ and summer $\left(R^{2}=0.09 ; p=0.009\right)$. The $\mathrm{CM}_{\mathrm{FF}}$ parameter shows similar pattern as $\mathrm{BC}_{\mathrm{FF}}$ to $\mathrm{NO}_{X}$.

The $\mathrm{BC}_{\mathrm{WB}}$ concentration has a different diurnal pattern than $\mathrm{BC}_{\mathrm{FF}}$. In general, there is a peak in the $\mathrm{BC}_{\mathrm{WB}}$ concentration from 19:00 to 03:00 (Fig. 3f), which indicates that most residents warm their houses by wood burning during the evenings and nights. Previous studies have found a similar diurnal pattern for wood-burning-derived emissions (Favez et al., 2010; Harrison et al., 2012, 2013; Kristensson et al., 2013; Wang et al., 2011).

$\mathrm{NO}_{X}$ is not thought to be emitted in large quantities from wood burning, but $\mathrm{NO}_{X}$ and $\mathrm{CM}_{\mathrm{WB}}$ concentrations are still correlated during the whole measurement period $\left(R^{2}=0.31\right.$; $p<0.01)$. This can be explained by the fact that both parameters are strongly seasonal dependent, but for different reasons. $\mathrm{NO}_{X}$ is mainly emitted from traffic, a source with usually low seasonal dependence. However, since $\mathrm{NO}_{X}$ is susceptible to photo-oxidation, its lifetime will be decreased during summer and increased during winter. Hence, observed $\mathrm{NO}_{X}$ concentrations may be lower during summer and elevated during winter. $\mathrm{CM}_{\mathrm{WB}}$ concentrations will be elevated during winter when residents heat their homes and mostly

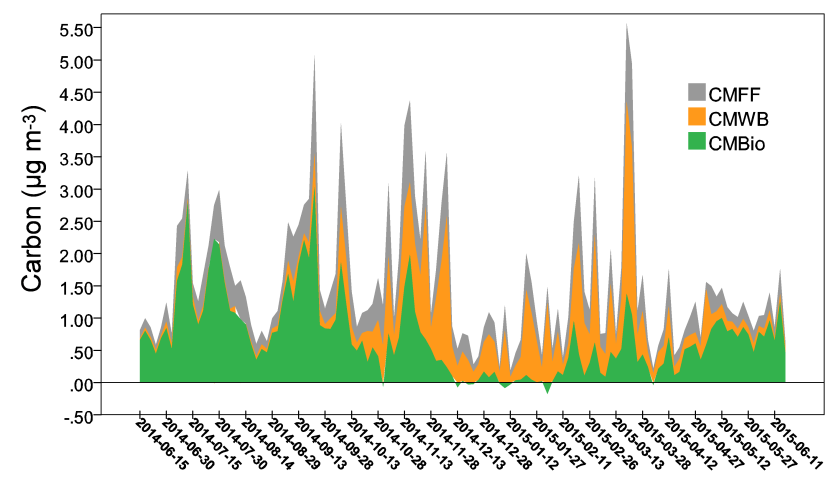

Figure 4. Aethalometer model source apportionment of total carbon from the Vavihill measurement station, June 2014-June 2015. $N=123$.

absent during summer. Hence, the correlation is strong but causality is most likely absent between them.

The seasonal patterns of other Aethalometer-modelderived parameters are presented in Table 4 and Fig. 4. It is clear that the wood-burning-derived carbonaceous aerosol, $\mathrm{CM}_{\mathrm{WB}}$, follows a seasonal cycle with high concentrations during fall (mean $=0.49 \mu \mathrm{g} \mathrm{m}^{-3}$ ), winter $\left(\right.$ mean $\left.=0.65 \mu \mathrm{g} \mathrm{m}^{-3}\right)$ and spring $\left(\right.$ mean $\left.=0.51 \mu \mathrm{g} \mathrm{m}^{-3}\right)$ and low levels during summer $\left(\right.$ mean $=0.07 \mu \mathrm{g} \mathrm{m}^{-3}$ ). The $\mathrm{CM}_{\mathrm{WB}}$ peaks with $5 \%$ contribution to $\mathrm{PM}_{10}$ during winter, while in summer the $\mathrm{CM}_{\mathrm{WB}}$ contribution is low $(0.6 \%)$. The $\mathrm{CM}_{\mathrm{WB}}$ contribution to TC peaks in winter with $56 \%$ and is reduced to $6 \%$ during summer. Hence, it is likely that the largest part of wood burning is conducted with the purpose of residential heating, as in contrast to decorative burning, which can be expected independently of outdoor temperature.

The fossil-fuel-derived parameter, $\mathrm{CM}_{\mathrm{FF}}$, shows a less distinct seasonal pattern than $\mathrm{CM}_{\mathrm{WB}}$, most probably because the main source, traffic, has a much smaller seasonal variation than wood burning. $\mathrm{CM}_{\mathrm{FF}}$ contributed $2-4 \%$ to $\mathrm{PM}_{10}$ during the year (21-35\% contribution to TC) with a maximum during spring and a minimum during summer. Finally, the biogenic aerosol carbon concentrations are substantial during summer $\left(9 \%\right.$ of $\mathrm{PM}_{10} ; 72 \%$ of TC) and low during winter $\left(0.9 \%\right.$ of $\mathrm{PM}_{10} ; 8 \%$ of TC). 


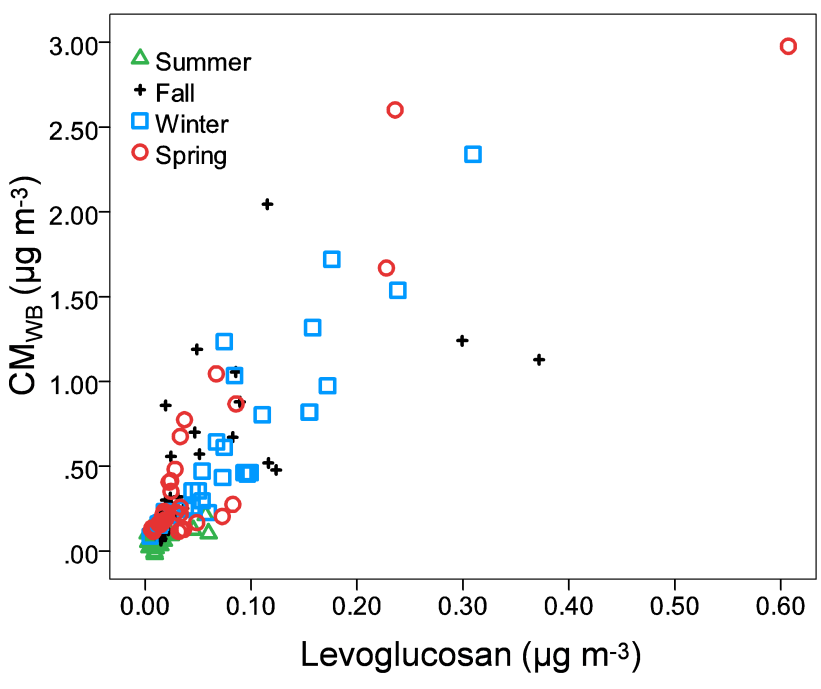

Figure 5. Comparison between $\mathrm{CM}_{\mathrm{WB}}$ and levoglucosan. $R^{2}=$ $0.70, N=122$.

\subsection{Comparison: levoglucosan to Aethalometer model}

Levoglucosan concentrations displayed an annual variation with elevated concentrations during the cold period of the year (Fig. S6). Mean concentrations during fall, winter and spring were $0.061(\mathrm{SD} \pm 0.082), 0.086$ $(\mathrm{SD} \pm 0.073)$ and $0.063(\mathrm{SD} \pm 0.115) \mu \mathrm{g} \mathrm{m}^{-3}$, respectively. The summertime mean levoglucosan concentration was $0.014(\mathrm{SD} \pm 0.0142) \mu \mathrm{g} \mathrm{m}^{-3}$. There was a significant difference between winter and summer $(p=0.03)$. Measured concentration levels and seasonal patterns were similar to those found by Genberg et al. (2011) at the same measurement site. The Aethalometer-model-derived carbonaceous matter from wood burning, $\mathrm{CM}_{\mathrm{WB}}$, correlated well with levoglucosan (Fig. 5, $R^{2}=0.7 ; p<0.001$ ). The correlation was strongest during winter $\left(R^{2}=0.82\right)$ and spring $\left(R^{2}=0.81\right)$ and lower during fall $\left(R^{2}=0.37\right)$ and summer $\left(R^{2}=0.30\right)$. Mean measured levoglucosan per unit of $\mathrm{BC}_{\mathrm{WB}}$ was estimated to be 0.64 (standard deviation $=0.73$ ). Previous wood stove measurements report mean levoglucosan to EC ratio of 0.82 (Iinuma et al., 2007; Schmidl et al., 2008). Thus, the estimated ratios presented in this study are in line with emission inventories from wood stoves. The measured ratios in comparison to references imply that the atmospheric decomposition of levoglucosan is in general slow, at least during the cold seasons. Another possibility is that the wood burning sources are located fairly close to the sampling site.

Further, $\mathrm{CM}_{\mathrm{FF}}$ is also correlated with levoglucosan throughout the whole year $\left(R^{2}=0.39 ; p<0.001\right)$. This finding is in contrast to Herich et al. (2011), who found no correlation between $\mathrm{BC}_{\mathrm{FF}}$ and levoglucosan in the Alpine regions of Switzerland. One explanation might be inaccurate apportionment where the wood burning aerosol exhibits an AAE close to 1 and is thus apportioned as fossil fuel aerosol.

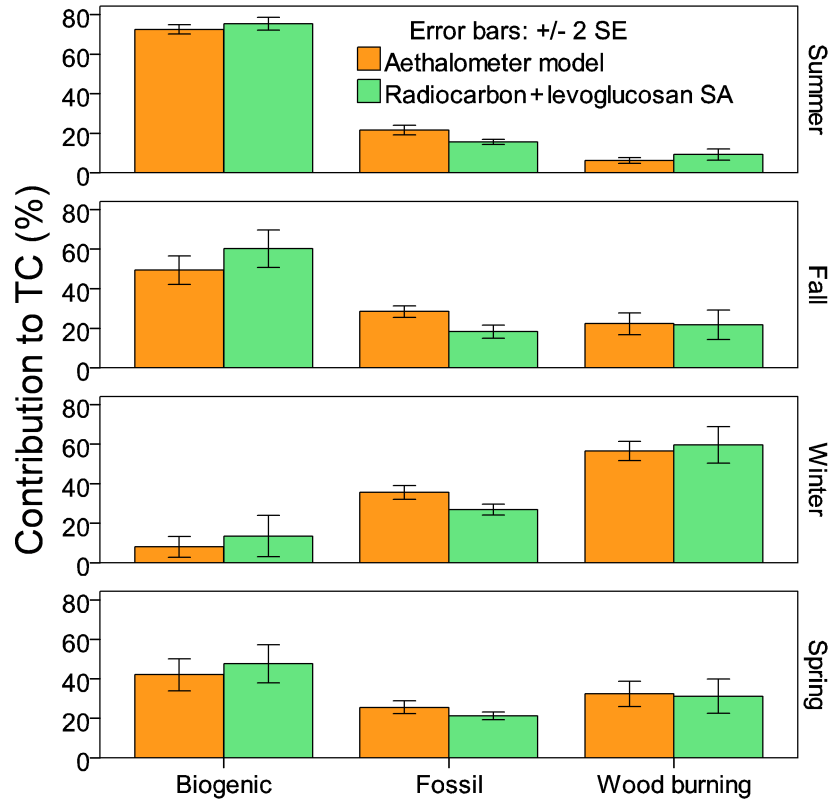

Figure 6. Seasonal comparison of source contribution to total carbon (TC) between the Aethalometer model and radiocarbon + levoglucosan source apportionment (SA). Error bars display 2 times standard error of the mean (SE).

This hypothesis is supported by the study of Martinsson et al. (2015), but whether this phenomenon would be more common and pronounced in Swiss Alpine regions in comparison to southern Sweden is unknown.

\subsection{Aethalometer model evaluation by radiocarbon and levoglucosan source apportionment}

We used $\mathrm{F}^{14} \mathrm{C}$ and levoglucosan data (Figs. S6-S7) applied to the method proposed by Bonvalot et al. (2016) to evaluate the Aethalometer model parameters. In Eq. (18), $a$ was set to 8.32 based on results from linear regression between winter values of $\mathrm{TC}_{\mathrm{NF}}$ and levoglucosan. The apportioned fossil fuel carbon fraction from the $\mathrm{F}^{14} \mathrm{C}$ and levoglucosan method $\left(\mathrm{TC}_{\mathrm{FF}}\right)$ is estimated to be $20 \%$ of $\mathrm{TC}$ throughout the year (Fig. 6), this is in good agreement with the previous studies from Vavihill measurement station (Genberg et al., 2011; Yttri et al., 2011a). However, there was a significant difference in fossil carbon apportioned between the two methods $(p=0.04)$. Throughout the year, the Aethalometer model overestimates the fossil carbon by a factor of $1.3 \mathrm{com}$ pared to $\mathrm{F}^{14} \mathrm{C}$ and levoglucosan source apportionment. Further, $\mathrm{TC}_{\mathrm{FF}}$ displays a better agreement with $\mathrm{NO}_{X}$ than the Aethalometer-model-derived $\mathrm{CM}_{\mathrm{FF}}\left(R^{2}=0.15 ; p<0.001\right.$ vs. $\left.R^{2}=0.06 ; p=0.007\right)$, indicating a more accurate apportionment of fossil carbon using $\mathrm{F}^{14} \mathrm{C}$.

Apportioned wood burning, $\mathrm{TC}_{\mathrm{WB}}$, showed a clear intraannual variability with high carbon contribution during winter $(60 \%)$ and low during summer $(9 \%)$, this is similar to 
the Aethalometer model, $\mathrm{CM}_{\mathrm{WB}}$, results. For the whole year, there was no significant difference in apportioned wood burning carbonaceous aerosol between the two methods $(p=$ $0.8)$.

The biogenic carbon fraction, $\mathrm{TC}_{\mathrm{Bio}}$, is dominating $\mathrm{TC}$ during summer $(75 \%)$, but is not negligible during winter (13\%, Fig. 6) in the radiocarbon and levoglucosan model. Apportioned biogenic carbon was in good agreement between the methods - i.e., no significant differences between the methods were observed for the whole year of data $(p=0.32)$.

Thus, with respect to apportioned wood burning and biogenic carbonaceous aerosol, the Aethalometer model setup presented in this paper shows good agreement with the radiocarbon and levoglucosan model. However, it is interesting to investigate two other possible setups of the model for a possibly more accurate Aethalometer model source apportionment of the fossil carbon: (a) to include the removed outliers in the linear regressions used to derive $\mathrm{C}_{1}$ and $\mathrm{C}_{2}$ and (b) to solve Eq. (9) with a bilinear fit, as originally proposed by Sandradewi et al. (2008a).

Including removed outliers would result in $\mathrm{C}_{1}$ and $\mathrm{C}_{2}$ parameters of 371047 and $88188 \mu_{\mathrm{g} \mathrm{m}}^{-2}$, respectively. The statistics for both linear regressions would improve, and the $R^{2}$ for $\mathrm{C}_{1}$ would, for instance, increase from 0.29 to 0.67 . However, increasing the $C_{1}$ parameter by a factor of 1.7 (from 214467 to $371047 \mu \mathrm{g} \mathrm{m}^{-2}$ ) would result in large discrepancies compared to the $\mathrm{F}^{14} \mathrm{C}$ and levoglucosan method. In general, for the whole measurement campaign, the fossil fuel contribution by the Aethalometer model would be overestimated by a factor of 2.4 , while the biogenic mass contribution would be underestimated by a factor of 1.7 compared to radiocarbon and levoglucosan source apportionment. The $\mathrm{CM}_{\mathrm{WB}}$ contribution to TC would be underestimated by a factor of 1.3 compared to $\mathrm{TC}_{\mathrm{WB}}$.

When we derived the $C_{1}$ and $C_{2}$ parameters by solving Eq. (9) as a multilinear fit (letting $\mathrm{CM}_{\text {Bio }}$ be a fixed intercept) $\mathrm{C}_{1}$ and $\mathrm{C}_{2}$ were determined as 497279 and $68859 \mu \mathrm{g} \mathrm{m}^{-2}$, respectively. $\mathrm{CM}_{\text {Bio }}$ was fixed to $-0.103 \mu \mathrm{g} \mathrm{m}^{-3}$. Hence, the multilinear solution provides a $\mathrm{C}_{1}$ parameter that is approximately 2.2 times larger than the $\mathrm{C}_{1}$ obtained by the current linear regression of Eq. (10), and a $C_{2}$ parameter that is 1.7 times smaller than the $C_{2}$ obtained by Eq. (11). The multilinear Aethalometer model solution should ideally be compared to radiocarbon and levoglucosan source apportionment results derived from Eq. (18) were $a$ was derived from a linear fit of winter data with an allowed intercept - i.e., biogenic carbon is allowed in $\mathrm{TC}_{\mathrm{NF}} . a$ is then determined as 7.16 with an intercept of 0.17 . This approach will lead to an overestimation of $\mathrm{CM}_{\mathrm{FF}}$ by a factor of 3.2 compared to $\mathrm{TC}_{\mathrm{FF}}$ and an underestimation of $\mathrm{CM}_{\mathrm{WB}}$ by a factor of 1.5 compared to $\mathrm{TC}_{\mathrm{WB}}$. Thus, a bilinear solution to Eq. (9) would increase the discrepancy between the Aethalometer model and the radiocarbon and levoglucosan source apportionment method.
Furthermore, we performed a sensitivity analysis with the aim of studying the impact of increased or decreased biogenic carbon during winter on the derived $C_{1}$ and $C_{2}$ parameters and the resulting source apportionment. In Eqs. (10) and (11) we increased and decreased the TC by +5 and $-5 \%$, respectively, without changing any of the $b_{\text {abs }}$ parameters. Thus, the induced change in TC will be analogous to changes in biogenic carbon concentration, assuming that this fraction is non-light-absorbing. A $5 \%$ change in TC led to a corresponding $5 \%$ change in the derived $\mathrm{C}_{1}$ and $\mathrm{C}_{2}$ parameters. Hence, increasing the non-light-absorbing TC would result in increased apportionment of TC into fossil fuel and wood burning; this would in turn result in a decreased apportionment to biogenic carbon. Increased concentrations of non-light-absorbing carbon by $5 \%$ during winter would result in an even larger annual significant overestimation of fossil fuel carbon by the Aethalometer model (a factor of 1.4 higher, $p=0.007$ ) in comparison to the $\mathrm{F}^{14} \mathrm{C}$ and levoglucosan source apportionment. However, this $5 \%$ increase would not result in a significantly different Aethalometer model apportionment of wood burning and biogenic carbon in comparison to the $\mathrm{F}^{14} \mathrm{C}$ and levoglucosan method. On the other hand, a $5 \%$ decrease in non-light-absorbing carbon would lead to better agreement in apportioned fossil fuel carbon between the Aethalometer model and the $\mathrm{F}^{14} \mathrm{C}$ and levoglucosan method. For the whole year, there would be no significant difference in apportioned fossil fuel carbon by the two methods $(p=0.137)$. Also, apportioned wood burning and biogenic carbon would not show any significant differences between the methods ( $p=0.941$ and $p=0.943$, respectively). Thus, the presence of non-light-absorbing carbon might explain the observed significant difference in apportioned fossil fuel carbon (Fig. 6). We conclude that the model is sensitive to non-light-absorbing carbon and that this fraction needs to be minimized in order for the model to function correctly.

\subsection{Air mass trajectory analysis}

For the whole measurement period, air masses arriving from SW dominated and contributed with $35 \%$ of the incoming air masses. The remaining contributions of the NW, SE and NE sectors were 32,17 and $16 \%$, respectively. Air masses arriving from SE were dominating during the fall $(31 \%)$ and were more polluted than air masses from other directions. $\mathrm{CM}_{\mathrm{FF}}$, $\mathrm{CM}_{\mathrm{WB}}$, levoglucosan and $\mathrm{PM}_{10}$ all increased with increasing fraction of incoming SE winds $(p<0.01)$. The elevated PM levels from this area can be explained by a large fraction of densely populated land and with air dominated by highpressure systems inhibiting vertical mixing with cleaner air.

An increasing fraction of $\mathrm{NE}$ air masses correlated with an increasing amount of biogenic aerosol $\left(\mathrm{CM}_{\mathrm{Bio}}, p<0.01\right)$, while other types of $\mathrm{PM}$ were low. $\mathrm{F}^{14} \mathrm{C}$ also increased with $\mathrm{NE}$ fraction $(p=0.03)$, supporting the impact of biogenic sources from this direction. This relation seems geographi- 
cally sound, due to the relatively large and sparsely populated land area. Further, since the abundance of incoming NE air masses was low during winter $(10 \%)$, the possible disturbance of biogenic carbon in the Aethalometer model should have been minimized.

The NW direction from Vavihill is dominated by the North Atlantic, North Sea and Norwegian Sea, which is displayed in the results; all carbonaceous PM species tend to decrease with increasing fraction of incoming air mass from NW $(p<0.01)$. Air masses arriving from this region can thus be considered relatively clean; this direction dominated during the summer (43\%). Finally, SW air masses tend to carry $\mathrm{NO}_{X}$, but no carbonaceous PM species correlates with this air mass direction. An increased fraction of SW air masses correlates with increased precipitation $(p<0.01)$; hence, it is possible that SW-related precipitation decreases carbonaceous PM through wet deposition while leaving the $\mathrm{NO}_{X}$ unaffected.

These results are in line with the findings of Kristensson et al. (2008), who found that air masses from the north were in general cleaner than air masses from continental Europe.

\subsection{Source apportionment uncertainty estimation by the propagation of errors}

Many source apportionment studies omit comprehensive uncertainty estimations. This can have severe impacts for decision and policymaking based on the studies. In the present study, an attempt to approximate measurement and linear estimation uncertainty on the calculated fractions of fossil fuel $\left(\mathrm{CM}_{\mathrm{FF}}\right)$, wood burning $\left(\mathrm{CM}_{\mathrm{WB}}\right)$ and biogenic $\left(\mathrm{CM}_{\mathrm{Bio}}\right)$ carbonaceous aerosol was conducted by the recommendations of Henry et al. (1984). The approach of propagation of errors was used and the most obvious uncertainties were estimated and summarized. Aethalometer measurements have been suggested to give an uncertainty of $5 \%$ to absorption coefficients (Hansen, 2005). However, recent work by Zanatta et al. (2016) proposes an uncertainty of $35 \%$ to Aethalometerderived absorption coefficients. We select the more conservative uncertainty of $35 \%$ for this analysis. $\mathrm{AAE}_{\mathrm{WB}}$ and $\mathrm{AAE}_{\mathrm{FF}}$ are associated with uncertainties of 30 and $10 \%$, respectively (Table 1). It should be noted that previous studies support our selection of AAEs (Massabo et al., 2015; Sandradewi et al., 2008b). The measured values of OC, EC and TC are associated with an uncertainty of $17 \%$ (Cavalli et al., 2016). Finally, the estimation of the $C_{1}$ and $C_{2}$ parameters were associated with uncertainties of 31 and $18 \%$, respectively. Considering that the fraction of fossil fuel combustion aerosol is based on Aethalometer measurements (absorption coefficients), $\mathrm{AAE}_{\mathrm{FF}}$, TOA (OC, EC, TC) and $\mathrm{C}_{1}$, this parameter get a total uncertainty of $41 \%$. Similarly, for the fraction wood burning aerosol, we base the total uncertainty on Aethalometer measurements, $\mathrm{AAE}_{\mathrm{WB}}$, TOA and $\mathrm{C}_{2}$. The overall uncertainty is then estimated to be $42 \%$. Despite the relatively high estimated uncertainty, it is worth noting that the $\mathrm{CM}_{\mathrm{WB}}$ agreement with levoglucosan was satisfactory (Fig. 5). Finally, we base the biogenic aerosol $\left(\mathrm{CM}_{\mathrm{Bio}}\right)$ uncertainty on Aethalometer measurements, $\mathrm{AAE}_{\mathrm{FF}}, \mathrm{AAE}_{\mathrm{WB}}$, $\mathrm{C}_{1}, \mathrm{C}_{2}$ and TOA. The biogenic carbonaceous aerosol fraction then reaches a total uncertainty of $50 \%$.

\section{Conclusions}

The Aethalometer model offers fast, inexpensive apportionment of the carbonaceous aerosol. The accuracy and robustness of the model principle has previously been questioned. In this study we propose a small modification to the Aethalometer model which enables apportioned nonabsorbing carbon, here assumed to be biogenic carbon, to vary. Propagation of errors showed that fossil, wood burning and biogenic carbonaceous aerosol quantification by the Aethalometer model may be highly uncertain. Nevertheless, we show that the model works well for a whole-year source apportionment for quantifying wood burning and variable biogenic carbonaceous aerosol at a rural site in southern Sweden, as there was a good agreement between Aethalometer model and the radiocarbon and levoglucosan source apportionment. The Aethalometer model overestimated the fossil carbonaceous aerosol compared to the radiocarbon and levoglucosan method, which may be explained by possible interference of non-light-absorbing biogenic carbon during winter. However, relating aerosol light absorption to carbon mass concentration by a bilinear solution or including statistically determined outliers resulted in even larger discrepancies between the two methods. Future studies are needed to investigate the repeatability of our proposed modified Aethalometer model.

Data availability. All data are accessible through the Supplement.

\section{The Supplement related to this article is available online at https://doi.org/10.5194/acp-17-4265-2017-supplement.}

Author contributions. Johan Martinsson designed the study and analyzed all data. Hafiz Abdul Azeem conducted levoglucosan analysis. Moa Sporre generated the HYSPLIT results. Erik Ahlberg and Emilie Öström were involved in the aerosol sampling. Adam Kristensson, Erik Swietlicki, Kristina Eriksson Stenström and Robert Bergström assisted in the writing process

Competing interests. The authors declare that they have no conflict of interest. 
Acknowledgements. This work was supported by the Swedish Research Council FORMAS (project 2011-743). The authors acknowledge research technician Mattias Olsson for graphitization and analysis of radiocarbon in filter samples.

Edited by: J. Allan

Reviewed by: two anonymous referees

\section{References}

Barregard, L., Sallsten, G., Gustafson, P., Andersson, L., Johansson, L., Basu, S., and Stigendal, L.: Experimental exposure to wood-smoke particles in healthy humans: Effects on markers of inflammation, coagulation, and lipid peroxidation, Inhal. Toxicol., 18, 845-853, https://doi.org/10.1080/08958370600685798, 2006.

Baxter, M. S. and Walton, A.: A Theoretical Approach to the Suess Effect, P. Roy. Soc. Lond. A Mat., 318, 213-230, 1970.

Benbrahim-Tallaa, L., Baan, R. A., Grosse, Y., Lauby-Secretan, B., El Ghissassi, F., Bouvard, V., Guha, N., Loomis, D., Straif, K., and Workin, I. A. R. C. M.: Carcinogenicity of diesel-engine and gasoline-engine exhausts and some nitroarenes, Lancet. Oncol., 13, 663-664, https://doi.org/10.1016/S1470-2045(12)70280-2, 2012.

Bond, T. C. and Bergstrom, R. W.: Light absorption by carbonaceous particles: An investigative review, Aerosol. Sci. Tech., 40, 27-67, https://doi.org/10.1080/02786820500421521, 2006.

Bond, T. C., Doherty, S. J., Fahey, D. W., Forster, P. M., Berntsen, T., DeAngelo, B. J., Flanner, M. G., Ghan, S., Karcher, B., Koch, D., Kinne, S., Kondo, Y., Quinn, P. K., Sarofim, M. C., Schultz, M. G., Schulz, M., Venkataraman, C., Zhang, H., Zhang, S., Bellouin, N., Guttikunda, S. K., Hopke, P. K., Jacobson, M. Z., Kaiser, J. W., Klimont, Z., Lohmann, U., Schwarz, J. P., Shindell, D., Storelvmo, T., Warren, S. G., and Zender, C. S.: Bounding the role of black carbon in the climate system: A scientific assessment, J. Geophys. Res.-Atmos., 118, 5380-5552, https://doi.org/10.1002/jgrd.50171, 2013.

Bonvalot, L., Tuna, T., Fagault, Y., Jaffrezo, J.-L., Jacob, V., Chevrier, F., and Bard, E.: Estimating contributions from biomass burning, fossil fuel combustion, and biogenic carbon to carbonaceous aerosols in the Valley of Chamonix: a dual approach based on radiocarbon and levoglucosan, Atmos. Chem. Phys., 16, 13753-13772, https://doi.org/10.5194/acp-16-137532016, 2016.

Calvo, A. I., Martins, V., Nunes, T., Duarte, M., Hillamo, R., Teinilae, K., Pont, V., Castro, A., Fraile, R., Tarelho, L., and Alves, C.: Residential wood combustion in two domestic devices: Relationship of different parameters throughout the combustion cycle, Atmos. Environ., 116, 72-82, https://doi.org/10.1016/j.atmosenv.2015.06.012, 2015.

Cavalli, F., Viana, M., Yttri, K. E., Genberg, J., and Putaud, J.-P.: Toward a standardised thermal-optical protocol for measuring atmospheric organic and elemental carbon: the EUSAAR protocol, Atmos. Meas. Tech., 3, 79-89, https://doi.org/10.5194/amt-3-792010, 2010.

Cavalli, F., Alastuey, A., Areskoug, H., Ceburnis, D., Cech, J., Genberg, J., Harrison, R. M., Jaffrezo, J. L., Kiss, G., Laj, P., Mihalopoulos, N., Perez, N., Quincey, P., Schwartz, J., Sellegri, K.,
Spindler, G., Swietlicki, E., Theodosi, C., Yttri, K. E., Aas, W., and Putaud, J. P.: A European aerosol phenomenology -4: Harmonized concentrations of carbonaceous aerosol at 10 regional background sites across Europe, Atmos. Environ., 144, 133-145, https://doi.org/10.1016/j.atmosenv.2016.07.050, 2016.

Clarke, A., McNaughton, C., Kapustin, V., Shinozuka, Y., Howell, S., Dibb, J., Zhou, J., Anderson, B., Brekhovskikh, V., Turner, H., and Pinkerton, M.: Biomass burning and pollution aerosol over North America: Organic components and their influence on spectral optical properties and humidification response, J. Geophys. Res.-Atmos., 112, D12S18, https://doi.org/10.1029/2006jd007777, 2007.

Day, D. E., Hand, J. L., Carrico, C. M., Engling, G., and Malm, W. C.: Humidification factors from laboratory studies of fresh smoke from biomass fuels, J. Geophys. Res.-Atmos., 111, D22202, https://doi.org/10.1029/2006jd007221, 2006.

Denier van der Gon, H. A. C., Bergström, R., Fountoukis, C., Johansson, C., Pandis, S. N., Simpson, D., and Visschedijk, A. J. H.: Particulate emissions from residential wood combustion in Europe - revised estimates and an evaluation, Atmos. Chem. Phys., 15, 6503-6519, https://doi.org/10.5194/acp15-6503-2015, 2015.

Doherty, S. J., Warren, S. G., Grenfell, T. C., Clarke, A. D., and Brandt, R. E.: Light-absorbing impurities in Arctic snow, Atmos. Chem. Phys., 10, 11647-11680, https://doi.org/10.5194/acp-1011647-2010, 2010.

Draxier, R. R. and Hess, G. D.: An overview of the HYSPLIT_4 modelling system for trajectories, dispersion and deposition, Aust. Meteorol. Mag., 47, 295-308, 1998.

Drinovec, L., Mocnik, G., Zotter, P., Prévôt, A. S. H., Ruckstuhl, C., Coz, E., Rupakheti, M., Sciare, J., Müller, T., Wiedensohler, A., and Hansen, A. D. A.: The "dual-spot" Aethalometer: an improved measurement of aerosol black carbon with realtime loading compensation, Atmos. Meas. Tech., 8, 1965-1979, https://doi.org/10.5194/amt-8-1965-2015, 2015.

EEA: Renewable energy in gross inland energy consumption, available at: http://www.eea.europa.eu/data-and-maps/indicators/ renewable-primary-energy-consumption-3/assessment, 2015.

Eriksson, A. C., Nordin, E. Z., Nyström, R., Pettersson, E., Swietlicki, E., Bergvall, C., Westerholm, R., Boman, C., and Pagels, J. H.: Particulate PAH Emissions from Residential Biomass Combustion: Time-Resolved Analysis with Aerosol Mass Spectrometry, Environ. Sci. Technol., 48, 7143-7150, https://doi.org/10.1021/es500486j, 2014.

Fabbri, D., Marynowski, L., Fabianska, M. J., Zaton, M., and Simoneit, B. R. T.: Levoglucosan and other cellulose markers in pyrolysates of miocene lignites: Geochemical and environmental implications, Environ. Sci. Technol., 42, 2957-2963, https://doi.org/10.1021/es7021472, 2008.

Favez, O., Cachier, H., Sciare, J., Sarda-Esteve, R., and Martinon, L.: Evidence for a significant contribution of wood burning aerosols to $\mathrm{PM}_{2.5}$ during the winter season in Paris, France, Atmos. Environ., 43, 3640-3644, https://doi.org/10.1016/j.atmosenv.2009.04.035, 2009.

Favez, O., El Haddad, I., Piot, C., Boréave, A., Abidi, E., Marchand, N., Jaffrezo, J.-L., Besombes, J.-L., Personnaz, M.-B., Sciare, J., Wortham, H., George, C., and D'Anna, B.: Intercomparison of source apportionment models for the estimation of wood burning aerosols during wintertime in an Alpine 
city (Grenoble, France), Atmos. Chem. Phys., 10, 5295-5314, https://doi.org/10.5194/acp-10-5295-2010, 2010.

Fuller, G. W., Tremper, A. H., Baker, T. D., Yttri, K. E., and Butterfield, D.: Contribution of wood burning to $\mathrm{PM}_{10}$ in London, Atmos. Environ., 87, 87-94, https://doi.org/10.1016/j.atmosenv.2013.12.037, 2014.

Fuzzi, S., Baltensperger, U., Carslaw, K., Decesari, S., Denier van der Gon, H., Facchini, M. C., Fowler, D., Koren, I., Langford, B., Lohmann, U., Nemitz, E., Pandis, S., Riipinen, I., Rudich, Y., Schaap, M., Slowik, J. G., Spracklen, D. V., Vignati, E., Wild, M., Williams, M., and Gilardoni, S.: Particulate matter, air quality and climate: lessons learned and future needs, Atmos. Chem. Phys., 15, 8217-8299, https://doi.org/10.5194/acp15-8217-2015, 2015.

Garg, S., Chandra, B. P., Sinha, V., Sarda-Esteve, R., Gros, V., and Sinha, B.: Limitation of the Use of the Absorption Angstrom Exponent for Source Apportionment of Equivalent Black Carbon: a Case Study from the North West Indo-Gangetic Plain, Environ. Sci. Technol., 50, 814-824, https://doi.org/10.1021/acs.est.5b03868, 2016.

Gelencser, A., May, B., Simpson, D., Sanchez-Ochoa, A., KasperGiebl, A., Puxbaum, H., Caseiro, A., Pio, C., and Legrand, M.: Source apportionment of $\mathrm{PM}_{2.5}$ organic aerosol over Europe: Primary/secondary, natural/anthropogenic, and fossil/biogenic origin, J. Geophys. Res.-Atmos., 112, D23S04, https://doi.org/10.1029/2006jd008094, 2007.

Genberg, J., Stenström, K., Elfman, M., and Olsson, M.: Development of graphitization of $\mu \mathrm{g}$-sized samples at Lund University, Radiocarbon, 52, 1270-1276, 2010.

Genberg, J., Hyder, M., Stenström, K., Bergström, R., Simpson, D., Fors, E. O., Jönsson, J. A., and Swietlicki, E.: Source apportionment of carbonaceous aerosol in southern Sweden, Atmos. Chem. Phys., 11, 11387-11400, https://doi.org/10.5194/acp-1111387-2011, 2011

Gilardoni, S., Vignati, E., Cavalli, F., Putaud, J. P., Larsen, B. R., Karl, M., Stenström, K., Genberg, J., Henne, S., and Dentener, F.: Better constraints on sources of carbonaceous aerosols using a combined ${ }^{14} \mathrm{C}$ - macro tracer analysis in a European rural background site, Atmos. Chem. Phys., 11, 5685-5700, https://doi.org/10.5194/acp-11-5685-2011, 2011.

Grahame, T. J., Klemm, R., and Schlesinger, R. B.: Public health and components of particulate matter: The changing assessment of black carbon, J. Air. Waste. Manage., 64, 620-660, https://doi.org/10.1080/10962247.2014.912692, 2014.

Grubbs, F. E.: Sample Criteria for Testing Outlying Observations, Ann. Math. Stat., 21, 27-58, https://doi.org/10.1214/aoms/1177729885, 1950.

Guenther, A., Hewitt, C. N., Erickson, D., Fall, R., Geron, C., Graedel, T., Harley, P., Klinger, L., Lerdau, M., Mckay, W. A., Pierce, T., Scholes, B., Steinbrecher, R., Tallamraju, R., Taylor, J., and Zimmerman, P.: A Global-Model of Natural Volatile Organic-Compound Emissions, J. Geophys. Res.-Atmos., 100, 8873-8892, https://doi.org/10.1029/94jd02950, 1995.

Hansen, A. D. A.: The Aethalometer, manual, Berkeley, California, USA, Magee Scientific, 2005.

Harrison, R. M., Beddows, D. C. S., Hu, L., and Yin, J.: Comparison of methods for evaluation of wood smoke and estimation of UK ambient concentrations, Atmos. Chem. Phys., 12, 82718283, https://doi.org/10.5194/acp-12-8271-2012, 2012
Harrison, R. M., Beddows, D. C. S., Jones, A. M., Calvo, A., Alves, C., and Pio, C.: An evaluation of some issues regarding the use of aethalometers to measure woodsmoke concentrations, Atmos. Environ., 80, 540-548, https://doi.org/10.1016/j.atmosenv.2013.08.026, 2013.

Hedberg, E. and Johansson, C.: Is levoglucosan a suitable quantitative tracer for wood burning? Comparison with receptor modeling on trace elements in Lycksele, Sweden, J. Air. Waste. Manage., 56, 1669-1678, 2006.

Hellborg, R. and Skog, G.: Accelerator mass spectrometry, Mass. Spectrom. Rev., 27, 398-427, https://doi.org/10.1002/mas.20172, 2008.

Hennigan, C. J., Sullivan, A. P., Collett, J. L., and Robinson, A. L.: Levoglucosan stability in biomass burning particles exposed to hydroxyl radicals, Geophys. Res. Lett., 37, L09806, https://doi.org/10.1029/2010gl043088, 2010.

Henry, R. C., Lewis, C. W., Hopke, P. K., and Williamson, H. J.: Review of Receptor Model Fundamentals, Atmos. Environ., 18, 1507-1515, https://doi.org/10.1016/0004-6981(84)90375-5, 1984.

Herich, H., Hueglin, C., and Buchmann, B.: A 2.5 year's source apportionment study of black carbon from wood burning and fossil fuel combustion at urban and rural sites in Switzerland, Atmos. Meas. Tech., 4, 1409-1420, https://doi.org/10.5194/amt-4-14092011, 2011.

Hoek, G., Brunekreef, B., Goldbohm, S., Fischer, P., and van den Brandt, P. A.: Association between mortality and indicators of traffic-related air pollution in the Netherlands: a cohort study, Lancet, 360, 1203-1209, https://doi.org/10.1016/S01406736(02)11280-3, 2002.

Hoffmann, D., Tilgner, A., Iinuma, Y., and Herrmann, H.: Atmospheric Stability of Levoglucosan: A Detailed Laboratory and Modeling Study, Environ. Sci. Technol., 44, 694-699, https://doi.org/10.1021/es902476f, 2010.

Iinuma, Y., Brüggemann, E., Gnauk, T., Müller, K., Andreae, M. O., Helas, G., Parmar, R., and Herrmann, H.: Source characterization of biomass burning particles: The combustion of selected European conifers, African hardwood, savanna grass, and German and Indonesian peat, J. Geophys. Res.-Atmos., 112, D08209, https://doi.org/10.1029/2006jd007120, 2007.

IPCC: Summary for policymakers, in: Climate Change 2013: The Physical Science Basis, Contribution of Working Group I to the Fifth Assessment Report of the Intergovernmental Panel on Climate Change, Cambridge, UK, New York, NY, USA, 2013.

Jacobson, M. Z.: Isolating nitrated and aromatic aerosols and nitrated aromatic gases as sources of ultraviolet light absorption, J. Geophys. Res.-Atmos., 104, 3527-3542, https://doi.org/10.1029/1998jd100054, 1999.

Jalava, P. I., Salonen, R. O., Nuutinen, K., Pennanen, A. S., Happo, M. S., Tissari, J., Frey, A., Hillamo, R., Jokiniemi, J., and Hirvonen, M. R.: Effect of combustion condition on cytotoxic and inflammatory activity of residential wood combustion particles, Atmos. Environ., 44, 1691-1698, https://doi.org/10.1016/j.atmosenv.2009.12.034, 2010.

Kirchstetter, T. W. and Thatcher, T. L.: Contribution of organic carbon to wood smoke particulate matter absorption of solar radiation, Atmos. Chem. Phys., 12, 6067-6072, https://doi.org/10.5194/acp-12-6067-2012, 2012. 
Kirchstetter, T. W., Novakov, T., and Hobbs, P. V.: Evidence that the spectral dependence of light absorption by aerosols is affected by organic carbon, J. Geophys. Res.-Atmos., 109, D21208, https://doi.org/10.1029/2004jd004999, 2004.

Kristensson, A., Dal Maso, M., Swietlicki, E., Hussein, T., Zhou, J., Kerminen, V. M., and Kulmala, M.: Characterization of new particle formation events at a background site in Southern Sweden: relation to air mass history, Tellus B, 60, 330-344, https://doi.org/10.1111/j.1600-0889.2008.00345.x, 2008.

Kristensson, A., Rissler, J., Löndahl, J., Johansson, C., and Swietlicki, E.: Size-Resolved Respiratory Tract Deposition of SubMicrometer Aerosol Particles in a Residential Area with Wintertime Wood Combustion, Aerosol Air Qual. Res., 13, 24-35, https://doi.org/10.4209/aaqr.2010.04.0025, 2013.

Lack, D. A., Bahreini, R., Langridge, J. M., Gilman, J. B., and Middlebrook, A. M.: Brown carbon absorption linked to organic mass tracers in biomass burning particles, Atmos. Chem. Phys., 13, 2415-2422, https://doi.org/10.5194/acp-132415-2013, 2013.

Laden, F., Schwartz, J., Speizer, F. E., and Dockery, D. W.: Reduction in fine particulate air pollution and mortality - Extended follow-up of the Harvard six cities study, Am. J. Resp. Crit. Care, 173, 667-672, https://doi.org/10.1164/rccm.200503443OC, 2006.

Laskin, A., Laskin, J., and Nizkorodov, S. A.: Chemistry of Atmospheric Brown Carbon, Chem. Rev., 115, 4335-4382, https://doi.org/10.1021/cr5006167, 2015.

Lewis, K., Arnott, W. P., Moosmüller, H., and Wold, C. E.: Strong spectral variation of biomass smoke light absorption and single scattering albedo observed with a novel dual-wavelength photoacoustic instrument, J. Geophys. Res.-Atmos., 113,D16203, https://doi.org/10.1029/2007jd009699, 2008.

Martinsson, J., Eriksson, A. C., Nielsen, I. E., Malmborg, V. B., Ahlberg, E., Andersen, C., Lindgren, R., Nyström, R., Nordin, E. Z., Brune, W. H., Svenningsson, B., Swietlicki, E., Boman, C., and Pagels, J. H.: Impacts of Combustion Conditions and Photochemical Processing on the Light Absorption of Biomass Combustion Aerosol, Environ. Sci. Technol., 49, 14663-14671, https://doi.org/10.1021/acs.est.5b03205, 2015.

Massabo, D., Caponi, L., Bernardoni, V., Bove, M. C., Brotto, P., Calzolai, G., Cassola, F., Chiari, M., Fedi, M. E., Fermo, P., Giannoni, M., Lucarelli, F., Nava, S., Piazzalunga, A., Valli, G., Vecchi, R., and Prati, P.: Multi-wavelength optical determination of black and brown carbon in atmospheric aerosols, Atmos. Environ., 108, 1-12, https://doi.org/10.1016/j.atmosenv.2015.02.058, 2015.

May, A. A., Saleh, R., Hennigan, C. J., Donahue, N. M., and Robinson, A. L.: Volatility of Organic Molecular Markers Used for Source Apportionment Analysis: Measurements and Implications for Atmospheric Lifetime, Environ. Sci. Technol., 46, 12435-12444, https://doi.org/10.1021/es302276t, 2012.

Mohr, C., Lopez-Hilfiker, F. D., Zotter, P., Prevot, A. S. H., Xu, L., Ng, N. L., Herndon, S. C., Williams, L. R., Franklin, J. P., Zahniser, M. S., Worsnop, D. R., Knighton, W. B., Aiken, A. C., Gorkowski, K. J., Dubey, M. K., Allan, J. D., and Thornton, J. A.: Contribution of Nitrated Phenols to Wood Burning Brown Carbon Light Absorption in Detling, United Kingdom during Winter Time, Environ. Sci. Technol., 47, 6316-6324, https://doi.org/10.1021/Es400683v, 2013.
Naeher, L. P., Brauer, M., Lipsett, M., Zelikoff, J. T., Simpson, C. D., Koenig, J. Q., and Smith, K. R.: Woodsmoke health effects: A review, Inhal. Toxicol., 19, 67-106, https://doi.org/10.1080/08958370600985875, 2007.

Pope, C. A. and Dockery, D. W.: Health effects of fine particulate air pollution: Lines that connect, J. Air. Waste Manage., 56, 709742, 2006.

Rafter, T. A. and Fergusson, G. J.: Atom Bomb Effect - Recent Increase of Carbon-14 Content of the Atmosphere and Biosphere, Science, 126, 557-558, https://doi.org/10.1126/science.126.3273.557, 1957.

Reimer, P. J., Brown, T. A., and Reimer, R. W.: Discussion: Reporting and calibration of post-bomb ${ }^{14} \mathrm{C}$ data, Radiocarbon, 46 , 1299-1304, 2004.

Rissler, J., Nordin, E. Z., Eriksson, A. C., Nilsson, P. T., Frosch, M., Sporre, M. K., Wierzbicka, A., Svenningsson, B., Löndahl, J., Messing, M. E., Sjögren, S., Hemmingsen, J. G., Loft, S., Pagels, J. H., and Swietlicki, E.: Effective Density and Mixing State of Aerosol Particles in a Near-Traffic Urban Environment, Environ. Sci. Technol., 48, 6300-6308, https://doi.org/10.1021/es5000353, 2014.

Roden, C. A., Bond, T. C., Conway, S., Benjamin, A., and Pinel, O.: Emission factors and real-time optical properties of particles emitted from traditional wood burning cookstoves, Environ. Sci. Technol., 40, 6750-6757, https://doi.org/10.1021/es052080i, 2006.

Saleh, R., Hennigan, C. J., McMeeking, G. R., Chuang, W. K., Robinson, E. S., Coe, H., Donahue, N. M., and Robinson, A. L.: Absorptivity of brown carbon in fresh and photo-chemically aged biomass-burning emissions, Atmos. Chem. Phys., 13, 76837693, https://doi.org/10.5194/acp-13-7683-2013, 2013.

Saleh, R., Robinson, E. S., Tkacik, D. S., Ahern, A. T., Liu, S., Aiken, A. C., Sullivan, R. C., Presto, A. A., Dubey, M. K., Yokelson, R. J., Donahue, N. M., and Robinson, A. L.: Brownness of organics in aerosols from biomass burning linked to their black carbon content, Nat. Geosci., 7, 647-650, https://doi.org/10.1038/Ngeo2220, 2014.

Salvi, S., Blomberg, A., Rudell, B., Kelly, F., Sandström, T., Holgate, S. T., and Frew, A.: Acute inflammatory responses in the airways and peripheral blood after short-term exposure to diesel exhaust in healthy human volunteers, Am. J. Resp. Crit. Care, 159, 702-709, 1999.

Sandradewi, J., Prevot, A. S. H., Szidat, S., Perron, N., Alfarra, M. R., Lanz, V. A., Weingartner, E., and Baltensperger, U.: Using aerosol light absorption measurements for the quantitative determination of wood burning and traffic emission contributions to particulate matter, Environ. Sci. Technol., 42, 3316-3323, https://doi.org/10.1021/Es702253m, 2008a.

Sandradewi, J., Prevot, A. S. H., Weingartner, E., Schmidhauser, R., Gysel, M., and Baltensperger, U.: A study of wood burning and traffic aerosols in an Alpine valley using a multi-wavelength Aethalometer, Atmos. Environ., 42, 101-112, https://doi.org/10.1016/j.atmosenv.2007.09.034, 2008b.

Schmidl, C., Marr, L. L., Caseiro, A., Kotianova, P., Berner, A., Bauer, H., Kasper-Giebl, A., and Puxbaum, H.: Chemical characterisation of fine particle emissions from wood stove combustion of common woods growing in midEuropean Alpine regions, Atmos. Environ., 42, 126-141, https://doi.org/10.1016/j.atmosenv.2007.09.028, 2008. 
Schnaiter, M., Horvath, H., Mohler, O., Naumann, K. H., Saathoff, H., and Schock, O. W.: UV-VIS-NIR spectral optical properties of soot and soot-containing aerosols, J. Aerosol Sci., 34, 14211444, https://doi.org/10.1016/S0021-8502(03)00361-6, 2003.

Sehlstedt, M., Dove, R., Boman, C., Pagels, J., Swietlicki, E., Löndahl, J., Westerholm, R., Bosson, J., Barath, S., Behndig, A. F., Pourazar, J., Sandström, T., Mudway, I. S., and Blomberg, A.: Antioxidant airway responses following experimental exposure to wood smoke in man, Part. Fibre Toxicol., 7, 21, https://doi.org/10.1186/1743-8977-7-21, 2010.

Simoneit, B. R. T.: Biomass burning - A review of organic tracers for smoke from incomplete combustion, Appl. Geochem., 17, 129-162, https://doi.org/10.1016/S0883-2927(01)00061-0, 2002.

Skog, G.: The single stage AMS machine at Lund University: Status report, Nucl. Instrum. Meth. B, 259, 1-6, https://doi.org/10.1016/j.nimb.2007.01.190, 2007.

Skog, G., Rundgren, M., and Sköld, P.: Status of the Single Stage AMS machine at Lund University after 4 years of operation, Nucl. Instrum. Meth. B, 268, 895-897, https://doi.org/10.1016/j.nimb.2009.10.058, 2010.

Stein, A. F., Draxler, R. R., Rolph, G. D., Stunder, B. J. B., Cohen, M. D., and Ngan, F.: Noaa's Hysplit Atmospheric Transport and Dispersion Modeling System, B. Am. Meteorol. Soc., 96, 20592077, https://doi.org/10.1175/Bams-D-14-00110.1, 2015.

Suess, H. E.: Radiocarbon Concentration in Modern Wood, Science, 122, 415-417, https://doi.org/10.1126/science.122.3166.415-a, 1955.

Szidat, S., Jenk, T. M., Synal, H. A., Kalberer, M., Wacker, L., Hajdas, I., Kasper-Giebl, A., and Baltensperger, U.: Contributions of fossil fuel, biomass-burning, and biogenic emissions to carbonaceous aerosols in Zurich as traced by ${ }^{14} \mathrm{C}$, J. Geophys. Res.Atmos., 111, D07206, https://doi.org/10.1029/2005jd006590, 2006

Unosson, J., Blomberg, A., Sandström, T., Muala, A., Boman, C., Nyström, R., Westerholm, R., Mills, N. L., Newby, D. E., Langrish, J. P., and Bosson, J. A.: Exposure to wood smoke increases arterial stiffness and decreases heart rate variability in humans, Part. Fibre Toxicol., 10, 20, 10.1186/1743-8977-10-20, 2013.

Wang, Y. G., Hopke, P. K., Rattigan, O. V., Xia, X. Y., Chalupa, D. C., and Utell, M. J.: Characterization of Residential Wood Combustion Particles Using the TwoWavelength Aethalometer, Environ. Sci. Technol., 45, 73877393, https://doi.org/10.1021/es2013984, 2011.

Weingartner, E., Saathoff, H., Schnaiter, M., Streit, N., Bitnar, B., and Baltensperger, U.: Absorption of light by soot particles: determination of the absorption coefficient by means of aethalometers, J. Aerosol Sci., 34, 1445-1463, https://doi.org/10.1016/S0021-8502(03)00359-8, 2003.

Wu, J., Hu, R., Yue, J., Yang, Z., and Zhang, L.: Study on the Derivatization Process Using N-O-bis(trimethylsilyl)trifluoroacetamide, $\quad \mathrm{N}$-(tert-butyldimethylsilyl)-Nmethyltrifluoroacetamide, Trimethylsilydiazomethane for the Determination of Fecal Sterols by Gas ChromatographyMass Spectrometry, Int. J. Chem. Mol. Nucl. Mater. Metallur. Eng., 2, 175-178, 2008.
Yttri, K. E., Simpson, D., Nøjgaard, J. K., Kristensen, K., Genberg, J., Stenström, K., Swietlicki, E., Hillamo, R., Aurela, M., Bauer, H., Offenberg, J. H., Jaoui, M., Dye, C., Eckhardt, S., Burkhart, J. F., Stohl, A., and Glasius, M.: Source apportionment of the summer time carbonaceous aerosol at Nordic rural background sites, Atmos. Chem. Phys., 11, 13339-13357, https://doi.org/10.5194/acp-11-13339-2011, 2011a.

Yttri, K. E., Simpson, D., Stenström, K., Puxbaum, H., and Svendby, T.: Source apportionment of the carbonaceous aerosol in Norway - quantitative estimates based on ${ }^{14} \mathrm{C}$, thermal-optical and organic tracer analysis, Atmos. Chem. Phys., 11, 9375-9394, https://doi.org/10.5194/acp-11-9375-2011, 2011 b.

Yttri, K. E., Schnelle-Kreis, J., Maenhaut, W., Abbaszade, G., Alves, C., Bjerke, A., Bonnier, N., Bossi, R., Claeys, M., Dye, C., Evtyugina, M., García-Gacio, D., Hillamo, R., Hoffer, A., Hyder, M., Iinuma, Y., Jaffrezo, J.-L., Kasper-Giebl, A., Kiss, G., LópezMahia, P. L., Pio, C., Piot, C., Ramirez-Santa-Cruz, C., Sciare, J., Teinilä, K., Vermeylen, R., Vicente, A., and Zimmermann, R.: An intercomparison study of analytical methods used for quantification of levoglucosan in ambient aerosol filter samples, Atmos. Meas. Tech., 8, 125-147, https://doi.org/10.5194/amt-8125-2015, 2015

Zanatta, M., Gysel, M., Bukowiecki, N., Müller, T., Weingartner, E., Areskoug, H., Fiebig, M., Yttri, K. E., Mihalopoulos, N., Kouvarakis, G. N., Beddows, D., Harrison, R. M., Cavalli, F., Putaud, J. P., Spindler, G., Wiedensohler, A., Alastuey, A., Pandolfi, M., Sellegri, K., Swietlicki, E., Jaffrezo, J. L., Baltensperger, U., and Laj, P.: A European aerosol phenomenology5: Climatology of black carbon optical properties at 9 regional background sites across Europe, Atmos. Environ., 145, 346-364, https://doi.org/10.1016/j.atmosenv.2016.09.035, 2016.

Zhao, R., Mungall, E. L., Lee, A. K. Y., Aljawhary, D., and Abbatt, J. P. D.: Aqueous-phase photooxidation of levoglucosan - a mechanistic study using aerosol time-of-flight chemical ionization mass spectrometry (Aerosol ToF-CIMS), Atmos. Chem. Phys., 14, 9695-9706, https://doi.org/10.5194/acp-149695-2014, 2014.

Zotter, P., Herich, H., Gysel, M., El-Haddad, I., Zhang, Y., Mocnik, G., Hüglin, C., Baltensperger, U., Szidat, S., and Prévôt, A S. H.: Evaluation of the absorption Ångström exponents for traffic and wood burning in the Aethalometer based source apportionment using radiocarbon measurements of ambient aerosol, Atmos. Chem. Phys. Discuss., https://doi.org/10.5194/acp-2016621, in review, 2016. 